\title{
Seamount effect on circulation and distribution of ocean taxa in the vicinity of La Pérouse, a shallow seamount in the southwestern Indian Ocean
}

\author{
Marsac Francis ${ }^{1,2,{ }^{*}}$, Annasawmy Pavanee ${ }^{1,2}$, Noyon Margaux ${ }^{3}$, Demarcq Herve ${ }^{1,2}$, Soria Marc ${ }^{1,2}$, \\ Rabearisoa Njaratiana ${ }^{1,2}$, Bach Pascal ${ }^{2,4}$, Cherel Yves ${ }^{6}$, Grelet Jacques ${ }^{7}$, Romanov Evgeny ${ }^{5}$
}

${ }^{1}$ MARBEC, Univ Montpellier, CNRS, Ifremer, IRD, Sète, France

2 Institut de Recherche pour le Développement (IRD), Sète, France

3 UK-SA NRF/DST Bilateral Research Chair: Ocean Sciences \& Marine Food Security, Nelson Mandela University, Port Elizabeth, South Africa

${ }^{4}$ MARBEC, Univ Montpellier, CNRS, Ifremer, IRD, Victoria, Seychelles

${ }^{5}$ CAP RUN - CITEB, Le Port, Île de La Réunion, France

${ }^{6}$ Centre D'Etudes Biologiques de Chizé (CEBC), UMR 7372 CNRS-La Rochelle Université, Villiers-enBois, France

7 IMAGO, IRD Bretagne, Technopole de Brest Iroise, Plouzané, France

* Corresponding author : Francis Marsac, email address : francis.marsac@ird.fr

\begin{abstract}
:
The La Pérouse seamount ( $60 \mathrm{~m}$ depth) has so far been poorly studied despite it being a short distance $(160 \mathrm{~km})$ from Réunion Island. As part of the MADRidge project, a multidisciplinary cruise was conducted to evaluate the effect of this shallow seamount on the local hydrology and ecology. Current measurements, temperature and chlorophyll-a profiles, and mesozooplankton and micronekton samples were collected between the summit and $35 \mathrm{~km}$ away. Micronekton data were supplemented with stomach content of pelagic top predators as well as fisheries statistics from the domestic longline fleet operating from Réunion. Vertical current profiles revealed distinct patterns between the offshore and seamountflanked stations, giving evidence of topographical induced flow instabilities, notably on its leeward side (west) relative to the east flank. Distinct patterns in temperature and chlorophyll-a vertical profiles suggest the formation of convergent and divergent circulation cells as a result of the irregular and crescent-like summit topography. Spatial differences in zooplankton abundance were detected with higher biovolumes on the leeward flank. The overall acoustic backscatter for micronekton over the summit was weaker than offshore, but highly concentrated in the upper layer. Albacore tuna and swordfish dominate the longline catch west of Réunion, seemingly in association with a deep $(900 \mathrm{~m})$ topographic feature. Yet the largest catch is not directly associated with La Pérouse which would be too shallow for top predators to aggregate around in the long term. Enhanced levels of phytoplankton or zooplankton enrichment at La Pérouse were not demonstrated in this study, nor was there notable diversity of micronekton species. This might explain the relatively limited importance of this seamount to the tuna fisheries in this region.
\end{abstract}

Keywords : bathymetry, mesoscale eddies, L-ADCP, mesozooplankton, micronekton, stomach contents, pelagic longline fisheries. 


\section{Seamounts and their importance}

Distinctive and often spectacular, seamounts are typically extinct volcanoes that rise abruptly above the surrounding deep-ocean floor but do not reach the sea surface; they are often referred to as undersea mountains (Wessel, 2007). Most are deep, but some come to within $100 \mathrm{~m}$ of the sea surface. They also commonly exist along ocean ridges. An example is the South West Indian Ridge that stretches $7700 \mathrm{~km}$ from Bouvet Island in the South Atlantic Ocean $\left(54^{\circ} 25^{\prime} \mathrm{S}, 3^{\circ} 22^{\prime} \mathrm{E}\right)$ to the Rodriguez triple junction at $70^{\circ} \mathrm{E}$ in the Indian Ocean (Munschy and Schlich, 1989; Sauter and Cannat, 2010; Figure 1a). Other examples are found in the northern Pacific, the volcanic 5800-km-long Hawaii-Emperor chain having >80 seamounts, and in the southern Pacific, the 4300-km-long Louisville Seamount Trail (Koppers et al., 2011). Seamounts arise from tectonic plate dynamics and mantle-melting anomalies (i.e. deep-mantle plumes known as hotspots).

Ship acoustic soundings are understandably limiting in terms of spatial coverage, but nowadays satellite altimetry can confidently detect seamounts taller than $\sim 1.5 \mathrm{~km}$, and studies have produced seamount catalogues holding some 14000 seamounts (Kitchingman et al., 2007) as shown in Figure 1a. Of these, 62\% are in the Pacific, 20\% in the Atlantic, $12 \%$ in the Indian, and $6 \%$ in the Southern oceans. Based on the size-frequency relationship for larger seamounts, Kitchingman et al. (2007) predicted more than 100000 seamounts $>1 \mathrm{~km}$ in height that remain uncharted. Globally, 50\% are within Exclusive Economic Zones (EEZ), but the proportion drops to $32 \%$ in the West Indian Ocean (FAO area 51). Harris et al. (2014), using a new digital global seafloor geomorphic features map (GSFM) recognised a total of 9951 seamounts and 283 guyots (seamounts with flat summits attributable to wave erosion), covering a total area of $8796150 \mathrm{~km}^{2}$ - approximately $30 \%$ of the global shelf region. As a consequence of more-restrictive criteria on (conical) seamount shape excluding reef-shaped features, Harris et al. (2014) counted less seamounts than in previous studies (Kitchingman et al., 2007; Yesson et al., 2011).

Seamounts represent a very special kind of biological hotspot in the deep ocean, often maintained by peculiar physics and resultant but fragile ecosystems. They often interact with ocean currents, creating high levels of variability in the mesoscale domain. Nearfield effects of seamounts have been predicted theoretically for several decades, but only recently has 
89

theory been confirmed by observation. Apart from altering flow patterns, the flowtopography interaction can cause Taylor columns and quasi-stationary eddies over and near seamounts, impacting both the benthic and pelagic communities overlying seamounts (White et al., 2007). Such interactions also cause downstream effects such as eddy fields (Huppert and Bryan, 1976; Herbette et al., 2003). These physical processes induce vertical water movement, resulting in nutrients moving into the photic layer of the ocean. Consequently, it is often hypothesised that seamounts carry above-average-size plankton populations that subsequently attract fish aggregations, which in turn fall prey to further predation, making seamounts important biological hotspots (Pitcher and Bulman, 2007). Suspension-feeding animals tend to dominate the summit and flanks of seamounts, creating dense benthic communities of cold-water stony corals, sea fans, black corals and sponges that in turn create habitat for numerous animals including dense aggregations of fish (Buhl-Mortensen et al., 2010). Rowden et al. (2010) found that seamounts support higher epibenthic megafaunal biomass than adjacent continental slopes. This increased productivity and aggregational effect is also an enticement for foraging seabirds that at times travel hundreds of kilometres to these feeding grounds. Haney et al. (1995) demonstrated that, relative to adjacent waters in the Central North Pacific, seabird density and biomass within the vicinity of seamount summits were 2.4 and 8 times higher, respectively, and highlighted that some seabird taxa can even be up to $40 \times$ more abundant around the studied seamount than in the wider Central North Pacific.

However, seamounts are also not all the same. They differ in form, size, depth and location, which combined with the ambient oceanography, creates unique local environmental and biogeographical conditions that impact faunal composition (Samadi et al., 2007). Along with geographic isolation, seamounts have been likened to oceanic islands, where endemism and species richness can be great (Barton, 1998). Certainly Taylor columns promote larval retention and aggregation (Boehlert and Mundy, 1993; Rogers, 1994; Mullineaux and Mills, 1997). Mullineaux and Mills (1997) and Richer de Forges et al. (2000) suggested that geographic isolation and retentive mechanisms could lead to a reduction in gene flow. Although the issue of the "island effect" and consequently unique seamount ecosystems is still unresolved, a review by Clark et al. (2010) concluded that seamounts do host diverse and abundant benthic communities, but often the composition is broadly similar to that of adjacent continental slopes. The same authors further indicate that whereas high levels of 
122

123

124

125

126

127

128

129

130

131

132

133

134

135

136

137

138

139

140

141

142

143

144

145

146

147

148

149

150

151

152

153

154

endemism on seamounts is found, the concept of "islands in the sea" is not well supported.

This is because connectivity levels between seamounts varies considerably, with some taxa having limited dispersal capabilities and hence localized distributions, and others with dispersal ranges of hundreds to thousands of kilometres.

The aggregation effect of seamounts is well-known by the commercial fishing industry, with many seamounts supporting (or formerly supporting) extensive fisheries, both pelagic (Fonteneau, 1991; Marsac et al., 2014) and benthic (Clark et al., 2007; Pitcher et al., 2010). In the 1960s, deep-sea trawlers in search of new fish stocks began to trawl seamounts and discovered large aggregations of commercially important fish species, targeting orange roughy (Hoplostethus atlanticus), oreos (Neocyttus rhomboidalis, Pseudocyttus maculatus), alfonsinos (Beryx splendens), grenadiers (Coryphaenoides rupestris) and toothfish (Dissostichus spp.) (Clark et al., 2007). Heavily built bottom trawls are towed from the summit down the flanks of seamounts to capture these fish. Many of the species are slowgrowing, long-lived and mature at a late age, so have low reproductive potential (Morato and Clark, 2007). Consequently, seamount fisheries typically collapse within a few years of initiation, with trawlers then moving on to other unexploited seamounts to maintain the fishery (Roberts, 2002; Norse et al., 2011). These long-lived seamount-associated fish species take a long time to recover, impeding seamount ecosystems restoring to their pristine conditions (Clark et al., 2019).

The heavy depletion of some fish stocks is not the only concern associated with seamount fishing. Trawling of seamounts can cause extensive damage to fragile coral communities, bringing up not only fish, but large numbers of corals, sponges and other benthic animals associated with the corals (FAO, 2006). Comparisons with unfished seamounts have shown the extent of habitat damage and loss of species diversity brought about by trawling, with the dense coral habitats reduced to rubble and devastating the ecosystem (Clark et al., 2019). Bottom fishing has not been limited to bottom trawls (70\% of the vessels), but also includes demersal longlines, demersal gillnets and traps (Bensch et al., 2009). Unsurprisingly, seamount fisheries have become controversial. Several regional fisheries management organisations have recognised vulnerable marine ecosystems (VMEs) and some have established fishing closures for trawling on seamounts (e.g. the Northwest Atlantic Fisheries Organization, NAFO, in 2006, Southern Indian Ocean Fisheries Agreement, SIOFA, in 
155

156

157

158

159

160

161

162

163

164

165

166

167

168

169

170

171

172

173

174

175

176

177

178

179

180

181

182

183

184

185

186

187

2018), along with compulsory bottom fishing impact assessment measures. However, as already noted, some $50 \%$ of seamounts exist in areas beyond national jurisdiction (ABNJ) in the global ocean, which brings additional difficulty in controlling and regulating fishing activities on them. Fishing represents one threat, but deep-sea mining and drilling activities would add another threat to benthic ecosystems of seamounts with mineral resources (Wessel, 2007). So far, only exploration contracts have been granted by the International Seabed Authority, ISA (Figure 1b), but through the Mining Code, protection measures have to be implemented by the contractors, including environmental management plans (ISA, 2019). Note here that the South West Indian Ridge is receiving particular attention.

Despite the large number of seamounts in the global ocean and the negative anthropogenic attention they have attracted, it appears that the future of such ecosystems lies in a delicate balance between protection and exploitation.

\section{Indian Ocean has fewest and least known seamounts}

As mentioned by Demopoulos et al. (2003), the seamounts of the Indian Ocean are among the least explored. As seen in Figure 1a, the majority of seamounts are located in the western part of the basin with the South West Indian Ridge (SWIR) being particularly conspicuous. Throughout the South West Indian Ocean (SWIO), the Soviet fleet targeted red mullet, also sometimes known as redbait (Emmelichthys nitidus) and rubyfish (Plagiogeneion rubiginosus), with catches peaking around 1980 and then decreasing in the mid-1980s (Clark et al., 2007; Rogers et al., 2017). Fishing switched to alfonsino in the 1990s as new seamounts were exploited. Some exploratory trawling was carried out on the Madagascar Ridge and SWIR by French vessels in the 1970s and 1980s, particularly targeting the Walters Shoal and Sapmer Bank (Collette and Parin, 1991). In the 1990s and early 2000s new fisheries developed in both regions. Along the SWIR, a major fishery developed on the high seas targeting orange roughy, black cardinal fish (Epigonus telescopus), pelagic armourhead (Pseudopentaceros wheeleri), oreos (Oreosomatidae) and alfonsino (Clark et al., 2007). In both cases, fisheries were characterised by a very rapid expansion of effort followed by a collapse in catches (Boyer et al., 2001; Branch, 2001; Clark et al., 2007). Thereafter, fishing shifted to the Madagascar Ridge, Mozambique Ridge and Mid-Indian Ocean Ridge, where they again targeted alfonsino and rubyfish (Clark et al., 2007). Much of this fishing is 
188

189

190

191

192

193

194

195

196

197

198

199

200

201

202

203

204

205

206

207

208

209

210

211

212

213

214

215

216

217

218

219

220

undertaken using bottom trawls with a high likelihood of significant adverse impacts on the vulnerable marine ecosystems such as the cold-water coral habitat, predicted or known on the seamounts in the region (Tittensor et al., 2009).

Two Soviet/Ukrainian research institutes (YugNIRO and Yugrybpoisk) undertook a huge research and exploratory fishing effort (mostly bottom and midwater trawls) on the SWIR (Romanov, 2003; FAO, 2017); more than 80 expeditions were conducted over three decades (1972-2000). The objective was to assess the fishing potential of this largely unknown area, with a focus on seamounts (Figure 2). Oceanographic and environmental observations were made during the expeditions. However, despite these and a series of intensive efforts during the unprecedented International Indian Ocean Expedition (IIOE) between 1959 and 1965 (Zeitzschel, 1973), the basin-scale ecology and the fauna inhabiting seamounts of the Indian Ocean, including the SWIR, are poorly known. This in part is due to the ocean's remoteness from nations with large-scale oceanographic research programmes. In an attempt to redress this knowledge deficit, the International Union for the Conservation of Nature (IUCN) in partnership with the United Nations Development Programme (UNDP) and the Global Environment Facility (GEF), supported a ship-based study between 2009 and 2013 to focus on the oceanography and pelagic ecology associated with six seamounts on the SWIR Coral Seamount, Melville Bank, Middle of What Seamount, Sapmer Bank and Atlantis Seamount - and one unnamed seamount on the Madagascar Ridge near Walters Shoal (Figure 3). Summit depths ranged from 90 to $1000 \mathrm{~m}$. The brief was to understand how pelagic ecosystems are influenced by the presence of seamounts, and of course the converse, how pelagic ecosystems interact with seamounts. The first expedition in 2009 used the RV Dr Fridtjof Nansen in affiliation with the Agulhas and Somali Current Large Marine Ecosystem (ASCLME) project, and focused on pelagic fauna. The second, in 2011, was devoted to the benthic realm using the RRS James Cook (Rogers et al., 2017).

The findings of the IUCN project represented a step change in the understanding of pelagic ecosystems and processes associated with seamounts in the SWIO. Results showed water mass to have a major effect on community structure across this complex and dynamic region, including the bacterioplankton, phytoplankton, pelagic invertebrates, other micronekton (fish) and even predators such as seabirds (Rogers et al., 2017). Processes likely to influence the distribution of both benthic and pelagic communities of megafauna, including species of 
221

222

223

224

225

226

227

228

229

230

231

232

233

234

235

236

237

238

239

240

241

242

243

244

245

246

247

248

249

250

251

252

253

fisheries interest, included internal tides and biological phenomena such as provision of additional habitat for prey species including micronektonic crustaceans and cephalopods (Rogers et al, 2017). The study emphasised that even limited sampling effort can significantly improve knowledge of the biodiversity and ecology of that remote part of the Indian Ocean, and moreover, contribute to understanding of seamount ecology in general.

\section{Seamounts in the vicinity of the Madagascar Ridge — regions of high productivity?}

\subsection{Prominent seamounts}

The Madagascar Ridge is an area extending south of the Madagascar landmass with dimensions of some $400 \mathrm{~km}$ in width and $1300 \mathrm{~km}$ in length (Figure 3). Water depths over most of the plateau are between 2000 and $3000 \mathrm{~m}$. The southern half of the ridge rises to the prominent Walters Shoal seamount, which comes within $18 \mathrm{~m}$ of the surface. South of Walters Shoal, the water depth increases rapidly to more than $3000 \mathrm{~m}$. Beyond this, the 4000 $m$ isobath joins the SWIR. The 'top' of the seamount has collapsed, and has an average depth around $50 \mathrm{~m}$, with a broken and jagged relief at the edge (more detailed maps are presented later, in Figure 7). The summit is rather bare and covered with massive blocks of calcareous coralline algae (P. Bouchet, pers. comm.). The northern part of the ridge also has several seamounts (>750 m), and one, referred to in our study as the MAD-Ridge seamount, rises to a depth of $240 \mathrm{~m}$ below the sea surface $\left(27^{\circ} 29^{\prime} \mathrm{S}, 46^{\circ} 16^{\prime} \mathrm{E}\right)$. The western side of the ridge is a steep scarp that runs down into the $5000 \mathrm{~m}$ deep Mozambique Basin. The slope of the eastern flank is gentler, leading into the 5000-6000 m deep Madagascar Basin.

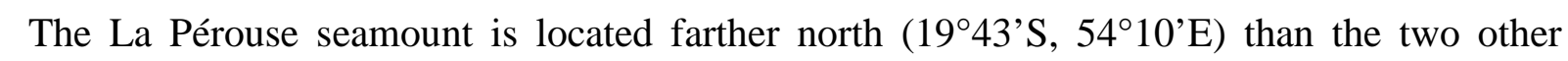
seamounts, $160 \mathrm{~km}$ northwest of Réunion Island. It is an extinct volcano reaching $60 \mathrm{~m}$ below the sea surface and is surrounded by an abyssal plain at $5000 \mathrm{~m}$ - making it a very isolated pinnacle. Owing to the collapse of one side of the seamount, La Pérouse as we know it today has a crescent-shaped summit instead of the more common conical shape of MADRidge and Walters Shoal.

\subsection{Seabirds and marine mammals}

Unlike the eastern Indian Ocean, the western portion is interspersed with islands, which provide a sanctuary for seabirds, a breeding habitat for an estimated 7.4 million pairs totalling 
254

255

256

257

258

259

260

261

262

263

264

265

266

267

268

269

270

271

272

273

274

275

276

277

278

279

280

281

282

283

284

285

286

31 species (Le Corre et al., 2012). Telemetry tracking data collected between 2003 and 2011 by Le Corre et al. (2012) revealed oceanic areas with particularly high seabird density in relation to breeding and foraging (Figure 4a). Seychelles and the Madagascar Ridge (south to the Walters Shoal) are the most populated areas, with a few dense spots also found in the Mozambique Channel and in the Mascarene Basin.

The Madagascar Ridge area is a major foraging ground of two seabird species - the redtailed tropicbird (Phaethon rubricauda) and Barau's petrel (Pterodroma baraui) (Le Corre et al., 2012). The red-tailed tropicbird has nine breeding sites in the western Indian Ocean, with the islands of Europa and Nosy Vé in the southern Mozambique Channel hosting almost half the entire population (Le Corre and Jouventin, 1997; Le Corre and Bemanaja, 2009). Barau's petrel, an endemic and endangered species from Réunion Island, also uses the Madagascar Ridge as foraging ground (Pinet et al., 2012; Le Corre et al., 2012; Figure 4b). They alternate between long and short foraging trips during the chick-rearing period (January-April), foraging over the Walters Shoal to replenish the adult reserves (Pinet et al., 2012). Isotope ratios measured on feathers indicate that the Black Bourbon's petrel (Pseudobulweria aterrima), another endemic and endangered species from Réunion Island, also feeds near Fort Dauphin on the southern Madagascar shelf, where upwelling is regular (Ramanantsoa et al., 2018) and farther south on the Madagascar Ridge (S. Jaquemet, unpublished data). In the Mascarene Basin, the only notable seabird hotspot is Tromelin Island (15'53'S, 54 $31^{\prime} \mathrm{E}$ ), characterised by two species of booby (Sula dactylatra and S. sula), and do not move far offshore (Le Corre et al., 2012). Interestingly, seabird tracking shows no activity in the vicinity of La Pérouse.

Feeding habitat chosen by seabirds is usually a good indicator of high ocean productivity. The majority of tropical seabirds feed upon small epipelagic prey (Le Corre and Jaquemet, 2005) that are distributed within the upper $50 \mathrm{~m}$ of the water column. Many seabirds, not being able to dive deeper than a few metres, often rely on surface-dwelling predators such as tuna and dolphins, while hunting, to force fleeing prey up towards the surface making them accessible to seabirds (Harrison, 1990, Jaquemet et al., 2004, 2005, Potier et al., 2007, Hebshi et al., 2008). It is also well-known that tuna are attracted to seamounts (Dubroca et al., 2013, Marsac et al, 2014) making these ecosystems of paramount importance for higher trophic levels. 
It is furthermore noteworthy that the Madagascar Ridge is located on the migration route of several whale species from the SubAntarctic, especially the blue whale Balaenoptera musculus (Best et al., 2003) and the humpback whale Megaptera novaeangliae (Best et al., 1998). The Walters Shoal has been recognised as a possible 'staging post' in December for whales migrating south to the Antarctic. Humpback whales are also seen in abundance along the east and southwest coast of Madagascar in austral winter, along with the less numerous southern right whales Eubalaena australis (Rosenbaum et al., 2001). At La Pérouse, as revealed by satellite tagging, humpback whales gather and breed in the surrounding areas of the seamount during austral summer (Dulau et al, 2017).

\subsection{Fishing}

Apart from deep-sea trawling, the region around the Madagascar Ridge is also subject to pelagic longlining by Asian fleets (since the 1960s) and by Spanish, Portuguese and Réunion Island-based French longliners, since the 1990s (IOTC database, www.iotc.org/data-andstatistics). As shown in Figure 5, there are regional differences in the SWIO among the dominant species caught. Unlike the Mozambique Channel, where yellowfin tuna (Thunnus albacares) makes up the bulk of the longline catch, the situation is more diversified around the Madagascar Ridge, with swordfish (Xiphias gladius) the dominant species in the catch, supplemented by yellowfin and bigeye (T. obesus) tuna and albacore (T. alalunga). The Madagascar Ridge is in the middle of a west-east decreasing gradient in catches, with an average of 1000-1500 tonnes per $5^{\circ}$ square over the period 1995-2017 (IOTC database, www.iotc.org/data-and-statistics). In the vicinity of La Pérouse, tuna and billfish are only exploited by Réunion-based French longliners, which mostly fish the region between Réunion Island and Madagascar (Evano and Bourjea, 2012). Albacore and swordfish are the two species primarily targeted and caught around La Pérouse and other topographic rises west of Réunion Island (www.iotc.org/data-and-statistics).

The SWIO region, particularly south of Madagascar, is also subject to illegal, unreported and unregulated fishing (IUU), as elsewhere in the high seas (MRAG, 2005). At-sea-transshipment is one possible way for illegal catches to be merged with catches from legal fleets, and for that reason, trans-shipment activities must comply with strict rules established by the Indian Ocean Tuna Commission (IOTC) to combat IUU fishing. Boerder et al. (2018) used 
Automatic Identification System (AIS) vessel-tracking data to locate a IUU trans-shipment hotspot in the vicinity of the Madagascar Ridge.

\section{Oceanography in the vicinity of the three prominent seamounts}

Most of what we know about the oceanography near the Madagascar Ridge has been gleaned from satellite observations and ocean models. Few oceanographic expeditions have been there, including during the era of the IIOE (1959-1965). Basic oceanographic data were collected by the Soviet and Ukraine fisheries expeditions in the 1970s and 1980s, but these are scant and not digitised (Romanov, 2003). In more recent years, the most notable scientific surveys have been in the northern region and include the Agulhas Current Sources Experiment in 2001 (ASCEX; Lutjeharms et al., 2000; de Ruijter et al., 2005), the Madagascar Experiment in 2005 (MadEx; Quartly, 2006), and the Agulhas Somalia Current Large Marine Ecosystem (ASCLME) Madagascar cruise in 2008 (Vousden et al., 2008). In 2013, a multidisciplinary cruise was undertaken to the Walters Shoal as part of the African Coelacanth Ecosystem Programme (ACEP); however, those data have not been published.

The longitudinal orientation and length of the Madagascar Ridge is such that it spans contrasting oceanographic conditions. The northern region is subject to high (total) kinetic energy (TKE) because of the termination of the southern branch of the East Madagascar Current (S-EMC) (Figure 6a). The S-EMC is a strong western boundary current that flows along the linear east Madagascar coast with speeds of $1.5 \mathrm{~m} \mathrm{~s}^{-1}$ (Voldsund et al., 2017). On reaching the southern end of the shelf, the flow is understood to undergo several configurations (branches), each of which may only exist intermittently: (1) turns west towards the Agulhas Current (e.g. Gründlingh, 1993); (2) or northwards into the Mozambique Channel (i.e. along the west coast of Madagascar (Srokosz et al., 2004), (3) retroflection eastwards (similar to the Agulhas Current) to join the shallow South Indian Ocean Counter Current (Palastanga et al., 2007; Siedler et al. 2009; Halo et al., 2014; Menezes et al., 2014), and (4) generation of eddies. At a mesoscale, the high kinetic energy observed in Figure $6 \mathbf{b}$ is mostly caused by cyclonic and anticyclonic eddies that spin up adjacent to the shelf, which then propagate west towards the African continent, at times as dipoles (de Ruijter et al., 2004; Ridderinkhof et al., 2013). Eddies are generated monthly with waves/trains of dipoles evident on time-scales of 3-4 months (Siedler et al, 2009). Models suggest that some $50 \%$ of the total 
353

354

355

356

357

358

359

360

361

362

363

364

365

366

367

368

369

370

371

372

373

374

375

376

377

378

379

380

381

382

383

384

385

S-EMC transport heads toward the Agulhas Current and that about $40 \%$ flows back into the central Indian Ocean, some via the South Indian Ocean Counter Current. Owing to the southward flow of the warm S-EMC, sea surface temperatures over the northern ridge are high, ranging seasonally between 23 and $26^{\circ} \mathrm{C}$ (climatological values; Vianello et al, 2020a).

Seasonal upwelling also develops on the continental shelf south of Madagascar (Lutjeharms and Machu, 2000; Machu et al., 2002; Ramanantsoa et al., 2018), which, apart from local ecological benefits, may also provide biological production (plankton) towards the northern part of the Madagascar Ridge, as seen in satellite observations depicting lengthy chlorophyll filaments extending off the shelf (e.g. de Ruijter et al., 2004; their Figure 1). This coastal upwelling appears to be driven by the easterly trade wind and at times the S-EMC (Ramanantsoa et al., 2018). The MAD-Ridge seamount at 27²9'S (200 km offshore), which rises to $240 \mathrm{~m}$ below the sea surface, is located in this very dynamic environment of eddies and retroflection of the S-EMC, and may also benefit from the biological production of the upwelling cell south of Madagascar.

The shallower Walters Shoal on the southern part of the Ridge at $33^{\circ} \mathrm{S}$ lies within a completely different dynamic environment - namely at the southern boundary of the South Indian Subtropical Gyre. As seen in Figure 6b, this seamount is located in a region of low kinetic energy (TKE), indicative of less mesoscale eddy activity. High TKE values are found south of the Walters Shoal, caused by eddy shearing of the Agulhas Return Current and Subtropical Front (Pollard and Read, 2015). With Walters Shoal being in the Gyre, surface currents tend to be weaker. Sea surface temperature climatologies indicate a seasonal range between 23 and $18^{\circ} \mathrm{C}$ (Vianello et al., 2020a).

The Madagascar Ridge is also located in a region of high internal tide energy (Zhao et al., 2016). Indeed, the entire Mascarene Sill-Madagascar Ridge-Mozambique Channel topographic complex is the epicentre of high internal tide generation in the Indian Ocean. Internal tides are generated by barotropic tidal currents flowing over steep bottom topography in the stratified oceans (Baines, 1982). Intense internal tidal energy is known to produce vertical mixing and diapycnal upliftment, which can stimulate local biological productivity (da Silva et al., 2002). Only two studies of internal tides have been undertaken in the SWIO to date. da Silva et al. (2009) found an internal tide generation hotspot at $20-21^{\circ} \mathrm{S}$ on the 
386

387

388

389

390

391

392

393

394

395

396

397

398

399

400

401

402

403

404

405

406

407

408

409

410

411

412

413

414

415

416

417

418

Sofala shelf in the Mozambique Channel, with a ray path towards the northern Madagascar Ridge. da Silva et al. (2011), also observed internal waves at the Mascarene Plateau. Satellite images (synthetic-aperture radar) reveal powerful internal waves radiating both to the west and east from a central sill near $13^{\circ} \mathrm{S}, 60^{\circ} 54^{\prime} \mathrm{E}$, between the Saya de Malha and Nazareth Banks. Nothing is known of internal waves south of Madagascar.

The La Pérouse seamount is also located in the South Indian Subtropical Gyre Province (Longhurst, 2007), as Walters Shoal is, but at a much lower latitude of $19^{\circ} 43^{\prime}$ S. Hence La Pérouse experiences warmer temperatures all year round (Noyon et al., 2020). La Pérouse is similarly subject to low TKE (Figure 6b), but is situated in the path of the west-flowing South Equatorial Current. Of all three seamounts, La Pérouse is situated in the most oligotrophic environment, highlighted by satellite observations of extremely low surface chlorophyll- $a$ concentrations with low variability, all year round (Jena et al., 2013; Noyon et al., 2020).

\section{The MADRidge Project (2016-2017)}

\subsection{Aims and Objectives}

As stated above, seamounts are often used as habitat and feeding grounds for fish and top predators. Certainly, fish catches and seabird observations show the Madagascar Ridge region with its varying shallow and deep seamounts to be an attractant. However, nothing is known of the underlying physical and biological mechanisms that promote the aggregations, or so-called hotspots of biodiversity. The overall aim of the MADRidge project was therefore to investigate this 'observed' heightened productivity, including the responsible physical processes, and to see whether seamounts are the underlying trigger. More precisely, the project aimed to obtain a first description of the pelagic ecosystems in the vicinity of the three regionally prominent shallow seamounts - MAD-Ridge $(240 \mathrm{~m})$, La Pérouse $(60 \mathrm{~m})$ and the Walters Shoal $(18 \mathrm{~m})$. From the large body of published knowledge, we hypothesised that interactions between currents and the seamount topographies were important contributors to enhanced productivity. We hoped to find evidence of enrichment through the vertical movement of deeper nutrient-rich water, and retention by Taylor columns. The spread of these seamounts also made a good case study for testing the influence of latitudinal effects $\left(20-33^{\circ} \mathrm{S}\right)$ and ambient contrasting hydrodynamic environments - with all three seamounts 
419

420

421

422

423

424

425

426

427

428

429

430

431

432

433

434

435

436

437

438

439

440

441

442

443

444

445

446

447

448

449

450

showing the presence of marine top predators (pelagic fish, marine mammals or seabirds) at least part of the year. Although benthos sampling was not possible in the MADRidge project, the spread, isolation and geographic location of the seamounts relative to the surrounding landmass also provided an opportunity to investigate connectivity in the region.

More specific scientific quests in the MADRidge project are given below. These provided guidance for the subcomponent studies published in this special issue.

a) What physical mechanisms are at play around seamounts and which are important for moving nutrients into the photic zone, in other words, the existence and role of mesoscale eddies, Taylor columns, slope upwelling, hydraulic jumps and vertical diapycnal mixing mechanisms such as internal tides, lee waves, and bores? All of these processes operate on temporal and spatial scales ranging from milliseconds to weeks, and from millimetres to hundreds of kilometres.

b) Do these physical processes linked to seamounts have a significant effect on the local ecosystem, i.e. is there upwelling and does production reside on the seamounts long enough for trophic transfer towards the upper levels of the foodweb?

c) In the case of MAD-Ridge, which is in an eddy-rich region, do seamount effects add extra productivity that makes the region special, i.e. is phytoplankton biomass increased at the top and on the slopes of the seamount? If so, do the assemblages differ from the open ocean? Is there a response in the zooplankton component, i.e. influencing biomass and taxa composition of the zooplankton communities on the slopes and around the seamount?

d) Is micronekton enhanced around the seamounts, i.e. do species composition and biomass of micronekton communities on the slopes and around the seamount differ? Also, does the presence of the seamount have any influence on the vertical day-night migration of micronekton?

e) Does the taxonomic composition of zooplankton and micronekton differ with latitude within the WIO?

f) Are seamounts conducive for spawning? If so, which species, and are larvae maintained near the seamount, and what are their connectivity with surroundings areas, i.e. which regions would benefit? 
451

452

453

454

455

456

457

458

459

460

461

462

463

464

465

466

467

468

469

470

471

472

473

474

475

476

477

478

479

480

481

482

483

Overarching these scientific issues, the MADRidge project aimed to provide scientific knowledge for a better understanding of seamount ecosystem functioning, which ultimately might be used to promote and design new management and conservation protocols for the seamounts of the SWIO (FFEM, 2019; Marsac et al, 2020b).

\subsection{A team of French-South Africa-Madagascar collaboration}

A multidisciplinary team of scientists, engineers and students was assembled representing the Institut de Recherche pour le Développement (France), Université de Bretagne Occidentale (France), Ifremer (France), Nelson Mandela University (South Africa), Branch Oceans and Coasts (DEA, South Africa), Université de la Réunion (ECOMAR), University of Cape Town (South Africa), Bayworld Centre for Research and Education (South Africa) and the Institut d'Halieutique et des Sciences Marines (IHSM), (Tuléar) Madagascar. Vessel time was provided by France, with some financial assistance from the Nelson Mandela University for the mooring recovery cruise out of Mauritius. Workshops were held in both South Africa and France to work the data into papers.

The MADRidge project was also supported by the FFEM-SWIO programme on the "Conservation and sustainable exploitation of deep-sea ecosystems of the South-West Indian Ocean away from national EEZ", funded by the Fonds Français pour l'Environnement Mondial (FFEM) and conducted by IUCN (FFEM, 2019)

\subsection{Ships, dates, surveys}

The MADRidge project was based mainly on observations around the summits of the three prominent seamounts (Figure 7) - MAD-Ridge (240 m), Walters Shoal (18 m) and La Pérouse $(60 \mathrm{~m})$. Two cruises were undertaken using the French vessels RV Antea (35 m) and one cruise with RV Marion Dufresne $(120 \mathrm{~m})$. The RV Antea has a scientific complement of 10 people. The RV Marion Dufresne, being larger, has an increased scientific complement, with part of her time dedicated to the logistics in the French TAAF (Terres Australes et Antarctiques Françaises). In all, 25 scientists were on board that vessel for the Walters Shoal cruise, 8 of which were from the MADRidge team. La Pérouse was surveyed between 15 and 30 September 2016 (RV Antea, doi: 10.17600/16004500), the MAD-Ridge seamount between 8 and 25 November 2016 for the first leg (RV Antea, doi: 10.17600/16004800) and 26 November to 13 December 2016 for the second leg (RV Antea, doi: 10.17600/16004900) 
484

485

486

487

488

489

490

491

492

493

494

495

496

497

498

499

500

501

502

503

504

505

506

507

508

509

510

511

512

513

514

515

and the Walters Shoal between 22 April and 18 May 2017 (RV Marion Dufresne, doi: 10.17600/ 17002700). Cruise data can be accessed by contacting the cruise chief scientists with reference to the doi ID of the cruises.

All three seamounts were sampled in similar ways, using a traditional suite of oceanographic instruments. Temperature, salinity, dissolved oxygen, fluorescence and light profiles through the water column were measured at all stations using a CTD-O 2 . A ship-mounted $(75 \mathrm{kHz})$ and Lowered (300 kHz) ADCP were used for along-track (0-600m depth range) and station current profiling, respectively. Seawater was sampled at different depths to measure nutrients $\left(\mathrm{NO}_{2}, \mathrm{NO}_{3}, \mathrm{PO}_{4}, \mathrm{Si}(\mathrm{OH})_{4}\right)$ in the upper $1000 \mathrm{~m}$ as well as phytoplankton pigments (within the euphotic layer), and to analyse the stable isotope signature of particulate organic matter (POM) and the picoplankton community (only MAD-Ridge Leg 1). Mesozooplankton and ichthyoplankton were collected using obliquely towed Bongo nets (200 and $500 \mu \mathrm{m})$ or a multinet $(200 \mu \mathrm{m})$. Micronekton distribution and biomass were studied using a hydroacoustic approach (Simrad EK 60 using 38, 70, 120 and $200 \mathrm{kHz}$ ) as well as midwater trawls (YGPT mesopelagic trawl with $10 \mathrm{~mm}$ mesh at La Pérouse and MAD-Ridge and an IsaacsKidd Midwater Trawl with $5 \mathrm{~mm}$ mesh at Walters Shoal). Temperature and salinity in the surface waters were also measured continuously using a thermosalinograph (TSG), which contributed to identifying mesoscale features during the cruises.

At La Pérouse, 11 hydrographic stations (CTD and plankton nets) were sampled, with 4 stations far from the seamount for comparison controls (Figure 7b). Ten trawls were deployed. The first leg of the MAD-Ridge cruise focused on the hydrography and circulation around the seamount, using a south-north and east-west sampling transect intersecting over the seamount summit (Figure 7c-d). In all, 31 stations were sampled over 17 days using a 12h operational schedule. Leg 2 consisted of a continuous survey made up of several triangles surrounding the seamount (not shown) and focused on the micronekton (hydro-acoustics and mesopelagic trawl). The Walters Shoal cruise, with its wider scope and being shared with the IUCN biodiversity project, consisted of a survey of two weeks of work onsite, with just $12 \mathrm{~h}$ per day dedicated to the pelagic component. The second half of each day was dedicated to the benthic component, which is not reported in this Special Issue. Owing to the shallow depth $(18-50 \mathrm{~m})$ and the size of the vessel, the centre of the seamount was not sampled. Stations (24 
516

517

518

519

520

521

522

523

524

525

526

527

528

529

530

531

532

533

534

535

536

537

538

539

540

541

542

543

544

545

546

547

548

in total) were selected around the summit and ranged in depth between $50 \mathrm{~m}$ and $1000 \mathrm{~m}$, with CTDs and plankton nets being deployed at each station (Figure 7e-f).

Two ADCP $(75 \mathrm{kHz})$ moorings with $400 \mathrm{~m}$ temperature and salinity (Seacat) arrays were deployed either side of the summit at the MAD-Ridge seamount in a depth of $600 \mathrm{~m}$. These were left for 2 years and only recovered in October 2018, using a chartered private vessel MV La Curieuse from Mauritius. These data were too late for inclusion in this issue.

\section{MADRidge project output synopsis}

From all the data collected, 13 papers (including this one) have been compiled, and are presented in this volume as a sequence covering ocean physics, ocean colour, plankton, ichthyoplankton, micronekton, connectivity, and seamount governance issues. As indicated above, the overall aim is to provide new knowledge to build an understanding of pelagic ecosystem functioning around seamounts in the SWIO.

The oceanography papers start by providing broad perspectives centred around the Madagascar Ridge of ocean circulation, eddy kinetic energy (EKE), and meridional gradients of sea surface temperature (SST), mixed layer depth (MLD), Total Heat Flux and chlorophyll (chl-a), all based on 20-year climatologies of satellite remote sensing data (Vianello et al., 2020a). For the ocean circulation in this seldom visited region, a novel approach is used. 'Virtual moorings' are created using a time-series of geostrophic currents derived from satellite altimetry. Together, the data highlight the contrasting environments experienced by the three prominent seamounts, and emphasise the overall longitudinal effect on the SWIO. A new technique based on generating a chl- $a$ enrichment index (EI) for the entire SWIO, is also developed, then used to demonstrate enhanced productivity at some of the seamounts as well as other features such as the continental shelves (Demarcq et al., 2020). The two studies mentioned in this paragraph serve as a backdrop to the other, more specialised papers.

The circulation and hydrography in the immediate vicinity of MAD-Ridge and La Pérouse are then investigated by Vianello et al., (2020b) and Marsac et al., (2020a), respectively. MAD-Ridge being in a very energetic environment, it was expected that the mesoscale dynamics there in the form of strong eddies and dipoles would be found to be the overriding 
549

550

551

552

553

554

555

556

557

558

559

560

561

562

563

564

565

566

567

568

569

570

571

572

573

574

575

576

577

578

579

580

581

driver of the physical processes, strongly influencing water masses, nutrient and chl- $a$ distributions (Vianello et al., 2020b), and moreover in our 'snapshot' cruise survey, somewhat obscuring any in situ observations of current-topography interactions and processes. Nevertheless, currents at MAD-Ridge were strong, and definitely (albeit small) changes in vertical density and temperature structures were observed around the summit and upper $400 \mathrm{~m}$ of slope, but any biological repercussions were outweighed by the presence of a powerful eddy dipole at the time of sampling. Analyses based on altimetry data showed the occurrence of eddies over MAD-Ridge to be common.

The classical seamount quest to observe retention cells, such as a Taylor column, at the three shallow seamounts is addressed in several papers. However, as with many seamount studies the world over, no conclusive in situ observational evidence is found. Theoretical considerations (calculations) using seamount shape, hydrological environment and ocean dynamics around the structures were generally not in favour of the development and maintenance of a Taylor column at certainly MAD-Ridge and La Pérouse (Annasawmy et al., 2020a), but was potentially possible around Walters Shoal (Demarcq et al., 2020).

The La Pérouse seamount received less attention in the physical oceanography, a consequence of a shorter field campaign (2 weeks), which had to collect many types of measurements - CTD stations, zooplankton tows, midwater trawls and attempts to sample demersal fish at the summit (Marsac et al., 2020a). Close examination of vertical current profiles, as well as nutrients and chl- $a$, showed strong, submesoscale flow instabilities adjacent $(0-3 \mathrm{~km})$ to the seamount, with slightly higher zooplankton biomass on the leeward (west) flank of the seamount relative to the eastern flank. These instabilities were generated by the seamount topography, and suggest an island-wake effect. Nevertheless, no remarkable biological enrichment directly associated with La Pérouse could be detected at the time of the cruise. This is an interesting finding, perhaps supported by the fact that neither seabird observations nor tuna catches are notably high in the vicinity of that seamount (Marsac et al., 2020a).

The impact of seamounts on the pelagic ecosystem is first tackled by Rocke et al. (2020), who focused on the MAD-Ridge seamount. They provide a description of the pico- and nanoplankton communities using flow cytometry. Both the mesoscale environment (dipole) 
582

583

584

585

586

587

588

589

590

591

592

593

594

595

596

597

598

599

600

601

602

603

604

605

606

607

608

609

610

611

612

613

614

and topographic effects were reflected in the abundance of picoplankton (higher in the anticyclonic eddy and on the slopes of the seamount) and nanoplankton (dominating in the cyclonic eddy). The differences in abundance found above the slopes of the seamount relative to farther afield are perhaps indicative of small-scale current turbulence caused by the topography and the mesoscale activity. Noyon et al. (2020) compared the mesozooplankton communities on the three seamounts using a size-based approach. They demonstrated no significant effect of the topography on zooplankton communities. Possibly not expected, the Walters Shoal had a lesser abundance and different size spectra than the two northern seamounts (MAD-Ridge and La Pérouse), where communities were typical of oligotrophic pelagic ecosystems dominated by small organisms. Seasonal variability is expected at the more temperate latitude of the Walters Shoal, whereas the influence of dynamic mesoscale structures could have masked seamount effects at the two other seamounts.

Of interest is the role of seamounts in being biodiversity hotspots and especially places in the deep ocean for larval recruitment. In this regard, the paper by Harris et al. (2020) analysed ichthyoplankton assemblages around all three of the seamounts. As for the mesozooplankton, no clear effect of seamount topography was observed on the fish larvae communities. However, a notable result is that neritic larvae were collected in high concentration on the MAD-Ridge seamount, emphasising the influence of the nearby Madagascar shelf in seeding the adjacent offshore environment (Crochelet et al., 2020; Noyon et al., 2019). Often in satellite observations, filaments of high chlorophyll are visible sweeping offshore for distances of several hundreds of kilometres, following contours of mesoscale structures such as eddies (de Ruijter et al., 2004).

Expanding this theme, Crochelet et al. (2020) used an Individually-Based Model (IBM) to further consider the degree of connectivity across and between these prominent seamounts. Results show a weak connectivity between La Pérouse, MAD-Ridge and the Walters Shoal and nursery grounds, as batches of 'artificial' larvae (particles) released at each seamount did not reach other suitable areas in substantial numbers. This suggests a mix of self-recruitment and immigration of larvae from nearby coastal areas must be happening at the seamounts, which is confirmed by Harris et al. (2020). Particle retention around the seamounts was greatest at Walters Shoal ( 10\%), with decreasing magnitudes at the MAD-Ridge seamount and La Pérouse (Crochelet et al., 2020). 
616 Micronekton form a crucial link in pelagic foodwebs connecting lower and upper trophic

617 levels. Annasawmy et al. (2020a), using complex hydro-acoustic techniques, examined the 618 micronekton distribution at the La Pérouse and MAD-Ridge seamounts. The data showed 619 that, at the mesoscale, the micronekton distribution responded mostly to the eddy dynamics, 620 following the diurnal dynamics of lower trophic levels (phyto- and zooplankton), with no strong evidence of any 'seamount effect' at both sites. However, at a local scale, the acoustic data clearly showed fish aggregation close to the summits of both seamounts, with trawl catches confirming the presence of seamount-associated species (Annasawy et al., 2020a).

Cherel et al. (2020) extended this work and examined the micronekton taxonomy on the three seamounts. They found three families of mesopelagic fish dominating at all three seamounts (myctophids, gonostomatids and sternoptychids), most of them being high-seas species. Few myctophids were pseudo-oceanic fish, highlighting the association with landmasses. The study by Annasawmy et al. (2020b) followed energy fluxes through the food chain using carbon and nitrogen stable isotope analyses on samples collected at La Pérouse and MADRidge. These ranged from particulate organic matter (POM) to micronekton (including gelatinous). Discrepancies between isotopic signatures for the two sites appeared at the lowest trophic levels, mostly reflecting the differences between the oligotrophic environment at La Pérouse and the more productive northern Madagascar Ridge. Overall, it appears that micronekton organisms occupy similar trophic positions at both seamounts despite varied feeding modes.

Returning to the MADRidge project aims, we confidently believe that we have provided comprehensive first descriptions of the pelagic ecosystems for the MAD-Ridge, La Pérouse and Walters Shoal seamounts. Our in situ data showed no evidence of Taylor columns and conspicuous current-topographic driven upwelling at these seamounts, although satellite data highlighted chlorophyll enrichment, particularly at the Walters Shoal. The lack of retentive mechanisms at the seamounts, combined with the results of the modelled connectivity study suggest that "oceanic island" effects are absent and therefore that high levels of endemism is unlikely. This is important for conservation measures. The WIO-wide climatologies of satellite-derived wind, SST, MLD, Total Heat Flux, EKE, Chl- $a$, show stark longitudinal (20647 $33^{\circ} \mathrm{S}$ ) change in these parameters, but hydrodynamic processes, especially at MAD-Ridge, 
648

649

650

651

652

653

654

655

656

657

658

659

660

661

662

663

664

665

666

667

668

669

670

671

672

673

674

675

676

677

678

679

680

conceal this effect on the biota. We also need to point out that important aspects that further complement these findings, such as mixing due to internal tides at MAD-Ridge and the formation of cross-shelf chl- $a$ filaments south of Madagascar, will be published later.

Finally, in keeping with the overarching aim of the MADRidge project, i.e. to provide scientific knowledge for the promotion and design of new management and conservation protocols for seamounts in the SWIO, we conclude this Special Issue with a final paper that raises seamount-related governance issues in the SWIO, with an emphasis on fisheries and conservation. In it, the Walters Shoal seamount, fished more than any other and located within an Area Beyond National Jurisdiction (ABNJ), is taken as a case study to explore a new format for marine protected areas (MPAs) that include seamounts in the high seas (Marsac et al., 2020b).

\section{Science into Governance}

The MADRidge project provides the first in-depth investigation of topographically coupled pelagic systems at three prominent shallow seamounts in the SWIO. The work adds to the regional body of knowledge already collected by the IUCN Seamounts project (Rogers et al., 2017). The IUCN project surveyed six seamounts on the SWIR, and one on the Madagascar Ridge north of the Walters Shoal (Figure 3). The MADRidge project presented here now adds the MAD-Ridge, Walter Shoals and La Pérouse seamounts to this body of knowledge.

In their review of key scientific areas required for improved management and conservation of seamounts, Clark et al. (2012) listed four important areas of required improvements (objectives): (1) new physical and biological research, (2) a global data repository, (3) new analysis tools, and (4) new impact research. We therefore now attempt to measure the scientific outputs of the IUCN Seamounts and MADRidge projects against the first two of these objectives ( 3 and 4 require additional resources and stakeholders).

The physical and biological knowledge acquired here makes good progress in describing many of the processes associated with seamounts, across a large latitudinal gradient (19$41^{\circ} \mathrm{S}$ ) and range of morphologies and depths (18-1000 m). As stated by Clark et al. (2012), we confirm that the diverse geological and oceanographic settings explain heterogeneity 
681

682

683

684

685

686

687

688

689

690

691

692

693

694

695

696

697

698

699

700

701

702

703

704

705

706

707

708

709

710

711

712

713

between seamounts in terms of flow instabilities along the slopes and biological responses, at least in the pelagic realm. The connectivity patterns, investigated by Lagrangian models at various spatial scales, are now better visualised in the SWIO and can be used in planning conservation measures. This is essential to identify the corridors that can drive gene flows between a series of seamounts. However, our description of the biodiversity at the three seamounts remains incomplete. Despite the pelagic biodiversity (represented by zooplankton, fish larvae, and micronekton, including fish, shrimps and squid, being measured at these seamounts, large knowledge gaps remain for the benthic biodiversity (with the exception of the Walters Shoal, where this was addressed during the cruise in 2017 - P. Bouchet, pers. comm.). Furthermore, for completeness, the structure of these ecosystems needs to be modelled. Only then can we have a complete or at least better understanding of the ecosystems.

Previously, only two areas have been surveyed scientifically, the seamounts of the Mozambique Ridge $\left(25-30^{\circ} \mathrm{S}\right.$ along $35^{\circ} \mathrm{E}$; Parin et al., 2008) in the 1970s/1980s, and the Walters Shoal with intermittent expeditions since 1964 (Clark, 1972; Collette and Parin, 1991; Parin et al., 1993), including the Marion Dufresne MD208 (doi: 10.17600/17002700) mounted by the MAD-Ridge project. Yet, corals and sponges represent the most fragile and diversified components of seamount biota, and are the first to be damaged by bottom trawls and mining. Benthic biodiversity surveys are undoubtedly activities that need to be promoted in future seamount expeditions. Such knowledge is essential to evaluate whether a seamount has fragile, rare or endemic species, or whether similarities exist with neighbouring seamounts in order to set up management measures at a larger spatial scale. Both the IUCN Seamounts and the MAD-Ridge projects have also contributed to improvements of seamount bathymetries in the SWIO (using single- and multi-beam sounders). These data too are essential for delimiting conservation areas, and have been provided to relevant data depositories.

To conclude, the scientific information collected on the SWIO seamounts is indeed incomplete and needs to be supplemented. Nevertheless, what is known today after these expeditions can allow refinement of management strategies and perhaps kick-off a sciencepolicy dialogue with WIO member states and regional management bodies specifically focused on seamounts. The Nairobi Convention (UNEP) is a key organisation competent in 
714

dealing with areas under national jurisdiction (EEZs), and possibly in the near future, in the ABNJ via the international legally binding instrument (ILBI) for the conservation and sustainable use of marine biodiversity, currently negotiated under the United Nations Convention for the Law of the Sea (UNCLOS). Indeed, seamounts are becoming a topic of concern at the Nairobi Convention (discussed at its $9^{\text {th }}$ Conference of Parties in 2018), under the scientific guidance of the Western Indian Ocean Marine Science Association (WIOMSA) and the IUCN. The Southern Indian Ocean Fisheries Agreement (SIOFA) is another key stakeholder in this dialogue, because it has already established five provisionally designated benthic protected areas that regulate fishing on seamounts.

In closing, although the MADRidge project has contributed a new, large body of knowledge on seamount functioning, it is clear that more seamount studies should be pursued in the SWIO to reveal the richness of the biota in this unique and seldom visited region. Only with this knowledge can we develop risk assessments and management strategies that have real impact.

\section{Acknowledgements}

The MADRidge project is part of the Western Indian Ocean Upwelling Research Initiative (WIOURI), endorsed by the International Indian Ocean Expedition 2 (IIOE2-EP04: https://iioe-2.incois.gov.in/IIOE-2/EP04.jsp) - specifically RUP 3 (Roberts, 2015). This project was a joint venture between the IRD (France) and the Nelson Mandela University in South Africa, with support from the UK Newton Fund and South African National Research Foundation (NRF) in the form of Prof. Roberts' UK-SA Bilateral Research Chair. Two French ships were supplied for the project - RV Antea and RV Marion Dufresne. Financial support for the cruises was provided by Fonds Français pour l'Environnement Mondial (FFEM), Flotte Océanographique Française, Région Réunion and Institut polaire français Paul Emile Victor (IPEV). We sincerely thank two anonymous reviewers for their valuable comments on the initial submission. 


\section{References}

Annasawmy, P., Cherel, Y., Romanov, E.V., Le Loc'h, F., Ménard, F, Ternon, J-F., Marsac, F., 2020b. Stable isotope patterns of mesopelagic communities over two shallow seamounts of the south-western Indian Ocean. Deep Sea Res. II (this issue).

Annasawmy, P., Ternon, J-F., Lebourges-Dhaussy, A., Roudaut, G., Cotel, P., Herbette, S., Ménard, F., Marsac, F., 2020a. Micronekton distribution as influenced by mesoscale eddies, Madagascar shelf and shallow seamounts in the south-western Indian Ocean: an acoustic approach. Deep Sea Res. II (this issue).

Baines, P. G., 1982. On internal tide generation models. Deep-Sea Res. 29, 307-338.

Barton, N.H., 1998. Natural selection and random genetic drift as causes of evolution on islands. In: Evolution on Islands (ed. Grant, P.R.), pp. 102-23. Oxford University Press, Oxford.

Bensch, A., Gianni, M., Greboval, D. Sanders, J., Hjort, A., 2009. Worldwide review of bottom fisheries in the high seas. FAO Tech. Pap. 522, 146 pp.

Best, P.B., Findlay, K.P., Sekiguchi, K., Peddemors, V.M., Rakotonirina, B., Rossouw, A., Gove, D., 1998. Winter distribution and possible migration routes of humpback whales Megaptera novaeangliae in the Southwest Indian Ocean. Mar. Ecol. Prog. Ser. 162, 287-299.

Best, P.B., Rademeyer, R.A., Burton, C., Ljungblad, D., Sekiguchi, K., Shimada, H., Thiele, D., Reeb, D., Butterworth, D.S., 2003. The abundance of blue whales on the Madagascar Plateau, December 1996. J. Cetacean Res. Man. 5(3): 253-260.

Biastoch, A., Beal, L.M., Casal, T.G.D., Lutjeharms, J.R.E., 2009. Variability and coherence of the Agulhas Undercurrent in a high-resolution ocean general circulation model. J. Phys. Oceanogr. 39, 2417-2435.

Boehlert, G.W. Mundy, B.C., 1993. Ichthyoplankton assemblages at seamounts and oceanic islands. Bull. Mar. Sci. 53, 336-361.

Boerder, K., Miller, N.A., Worm B., 2018. Global hot spots of trans-shipment of fish catch at sea. Sci. Adv, 4: eaat7159, 25 July 2018.

Boyer, D.C., Kirchner, C.H., McAllister, M.K., Staby, A., Staalesen B.I., 2001. The orange roughy fishery of Namibia: lessons to be learned about managing a developing fishery. In A Decade of Namibian Fisheries Science. Payne, A. I. L., Pillar, S. C. and R. J. M. Crawford (Eds). S. Afr. J. Mar. Sci. 23, 205-221.

Branch, T.A., 2001. A review of orange roughy Hoplostethus atlanticus fisheries, estimation methods, biology and stock structure. S. Afr. J. Mar. Sci. 23, 181-203.

Buhl-Mortensen, L., Vanreusel, A., Gooday, A.J., Levin, L.A., Priede, I.G., Buhl- Mortensen, P., Gheerardyn, H., King, N.J., Raes, M., 2010. Biological structures as a source of habitat heterogeneity and biodiversity on the deep ocean margins. Mar. Ecol. 31, 21-50.

Cherel, Y., Romanov, E.V., Annasawmy, P., Thibault, D., Ménard, F., 2020. Micronektonic fish species over three seamounts in the southwestern Indian Ocean. Deep Sea Res. II. (this issue).

Clark, A.M., 1972. Some crinoids from the Indian Ocean. Bull. Br. Mus. (Nat. Hist.) 24(2), 73-156.

Clark, M.R., Bowden, D.A., Rowden, A.A., Stewart, R., 2019. Little evidence of benthic community resilience to bottom trawling on seamounts after 15 years. Front. Mar. Sci. 6, 1-16. doi:10.3389/fmars.2019.00063

Clark, M.R., Rowden, A.A., Schlacher, T., Williams, A., Consalvey, M., Stocks, K.I., Rogers, A.D., O’Hara, T.D. White, M., Shank, T.M., Hall-Spencer, J.M. 2010. The 
ecology of seamounts: structure, function, and human impacts. A. Rev. Mar. Sci. 2010.2, 253-278.

Clark, M.R., Schlacher, T.A., Rowden, A.A., Stocks, K.I., Consalvey, M., 2012. Science priorities for seamounts: research links to conservation and management. PLoS ONE 7(1): e29232. doi:10.1371/journal.pone.0029232

Clark, M.R., Vinnichenko, V.I., Gordon, J.D.M., Beck-Bulat, G.Z., Kukharev, N.N, Kakora, A.F., 2007. Large-scale distant-water trawl fisheries on seamounts. In Pitcher, T.J., Morato, T., Hart, P.J.B., Clark, M.R., Haggan, N., Santos, R.S. (Eds), Seamounts: Ecology, Fisheries and Conservation 12. Blackwell Publishing, Oxford, U.K, 361-399.

Collette, B.B., Parin, N.V., 1991. Shallow-water fishes of Walters Shoals, Madagascar Ridge. Bull. Mar. Sci. 48, 1-22.

Crochelet, E., Barrier, N., Andrello, M., Marsac, F., Spadone, A., Lett, C., 2020. Connectivity between seamounts and coastal ecosystems in the Southwestern Indian Ocean. DeepSea Res. II (this issue).

da Silva, J.C.B., New, A.L., Magalhaes, J.M., 2009. Internal solitary waves in the Mozambique Channel: observations and interpretation. J. Geophys. Res. 114, C05001. doi:1 0.1029/2008JC005125.

da Silva, J.C.B., New, A., Srokosz, M., Smyth, T.J., 2002. On the observability of internal tidal waves in remotely-sensed ocean colour data. Geophys. Res. Lett. 29(12),10-1 10-4.

da Silva, J.C.B., New, A.L., Magalhaes, J.M., 2011. On the structure and propagation of internal solitary waves generated at the Mascarene Plateau in the Indian Ocean. DeepSea Res. I 58, 229-240. doi:10.1016/j.dsr.2010.12.003.

Demarcq, H., Noyon, M., Roberts, M.J., 2020. Satellite observations of phytoplankton enrichments around seamounts in the South West Indian Ocean, with a special focus on the Walters Shoal. Deep-Sea Res. II (this issue)

Demopoulos, A.W.J., Smith, C.R., Tyler, P.A., 2003. The deep Indian Ocean floor. In, Tyler, P.A. (ed.) Ecosystems of the World Vol. 28. Ecosystems of the Deep Oceans. Amsterdam, Netherlands. Elsevier, pp. 219-237.

de Ruijter, W.P.M., van Aken, H.M., Beier, E.J., Lutjeharms, J.R.E., Matano, R.P., Schouten, M.W., 2004. Eddies and dipoles around South Madagascar: formation, pathways and large-scale impact. Deep-Sea Res. I. 51(3), 383-400.

de Ruijter, W.P.M., Ridderinkhof H., Schouten M., 2005. Variability of the southwest Indian Ocean, Philos. Trans. R. Soc., 363, 63-76, doi:10.1098/rsta.2004.1478.

Dubroca, L., Chassot, E., Floch, L., Demarcq, Assan, C., Delgado de Molina, A., 2013. Seamounts and tuna fisheries: tuna hotspots or fishermen habits? Collectve Vol. Sci. Pap. ICCAT 69, 2087-2102.

Dulau, V., Pinet, P., Geyer, I., Fayan, J., Mongin, P., Cottarel, G., Zerbini, A., Cerchio, S., 2017. Continuous movement behavior of humpback whales during the breeding season in the Southwest Indian Ocean: on the road again. Mov. Ecol. 5:11 doi: 10.1186/s40462-017-0101-5.

Evano, H., Bourjea, J., 2012. Atlas de la pêche palangrière réunionnaise de l'océan Indien. RST -doi/2012-11. 245 pp

FAO, 2006. Expert consultation on deep-sea fisheries in the high seas. GCP/INT/942/JPN, FAO Fish. Rep. 838, 204 pp.

FAO, 2017. Fishery and Aquaculture Statistics. Global capture production 1950-2015 (FishstatJ). In: FAO Fisheries and Aquaculture Department [online]. Rome. Updated 2017.

FFEM, 2019. De la science à la gouvernance de la haute mer - Exploration et gestion des monts sous-marins du sud-ouest de l'océan Indien. Publication FFEM, Paris. 
Fonteneau, A., 1991. Monts sous-marins et thons dans l'Atlantique tropical est. Aquat Liv. Resour. 4, 13-25.

Grundlingh, M. L., 1993. On the winter flow in the southern Mozambique Channel. Deep Sea Res., Part A, 40, 409-418.

Halo, I., Penven, P., Backeberg, B., Ansorge, I., Shillington, F., Roman, R., 2014. Mesoscale eddy variability in the southern extension of the East Madagascar Current: seasonal cycle, energy conversion terms, and eddy mean properties. J. Geophys. Res. 119(10), 7324-7356.

Haney, J.C., Haury, L.R., Mullineaux, L.S., Fey, C.L., 1995. Seabird aggregation at a deep North Pacific seamount. Mar. Biol. 123, 1-9.

Harris, P.T., MacMillan-Lawler, M., Rupp, J., Baker, E.K., 2014. Geomorphology of the oceans. Marine Geology 352, 4-24.

Harris, S.A., Noyon, M., Marsac, F., Vianello, P., Roberts, M.J., 2020. Ichthyoplankton assemblages at three shallow seamounts in the South West Indian Ocean. Deep-Sea Res. II (this issue).

Harrison, C.S., 1990. Seabirds of Hawaii - Natural History and Conservation. Cornell University Press, New York, 249 pp.

Hebshi, A.J., Duffy, D.C., Hyrenbach, K.D., 2008. Associations between seabirds and subsurface predators around Oahu, Hawaii. Aquat. Biol. 4, 89-98.

Herbette, S., Morel, Y., Arhan, M., 2003. Erosion of a surface vortex by a seamount. J. Phys. Oceanogr. 33, 1664-1679.

Huppert, H., Bryan, K., 1976. Topographically generated eddies. Deep-Sea Res. 23, 655-679.

ISA, 2019. Report on the status of the contracts for exploration, Twenty-fifth session, Legal and Technical Commission session, part I Kingston, 4-15 March 2019, 7 pp.

Jaquemet, S., Le Corre, M., Marsac, F., Potier, M., Weimerskirch, H., 2005. Foraging habitats of the seabird community of Europa (Mozambique Channel). Mar. Biol. 147, 573-582.

Jaquemet, S., Le Corre, M., Weimerskirch, H., 2004. Seabird community structure in a coastal tropical environment: importance of natural factors and fish aggregative devices (FADs). Mar. Ecol. Prog. Ser. 268, 281-292.

Jena, B., Sahu, S., Avinash, K., Swain, D., 2013. Observation of oligotrophic gyre variability in the south Indian Ocean: environmental forcing and biological response. Deep-Sea Res. I. 80: 1-10. http://dx.doi.org/10.1016/j.dsr.2013.06.002

Kitchingman, A., Sherman, L., Morato, T, Pauly, D., 2007. How many seamounts are there and where are they located? In: Pitcher, T.J., Morato, T., Hart, P.J.B., Clark, M.R., Haggan, N., Santos, R.S. (Eds), Seamounts: Ecology, Fisheries and Conservation 12. Blackwell Publishing, Oxford, U.K, 26-40.

Koppers, A.A.P., Gowen, M.D., Colwell, L.E., Gee, J.S., Lonsdale, P.F., Mahoney, J.J., Duncan, R.A., 2011. New ${ }^{40} \mathrm{Ar} /{ }^{39} \mathrm{Ar}$ age progression for the Louisville hot spot trail and implications for inter-hot spot motion. Geochem. Geophys, Geosyst. 12(12), doi:10.1029/2011GC003804.

Le Corre, M., Bemanaja, E., 2009. Discovery of two major seabird colonies in Madagascar. Mar. Ornithol. 37, 153-158.

Le Corre, M., Jaeger, A., Pinet, P., Kappes, M.A., Weimerskirch, H., Catry, T., Ramos, J.M., Russell, J.C., Shah, N., Jaquemet, S., 2012. Tracking seabirds to identify potential marine protected areas in the tropical western Indian Ocean. Biol. Conserv. 156, 83-93 doi:hgq,q,;1016/j.biocom.2011.11.015

Le Corre, M., Jaquemet, S., 2005. Assessment of the seabird community of the Mozambique Channel and its potential use as an indicator of tuna abundance. Estuar. Coast. Shelf Sci. 63, 421-428. 
Le Corre, M., Jouventin, P., 1997. Ecological significance and conservation priorities of Europa Island (western Indian Ocean), with special reference to seabirds. Revue d'Ecologie 52, 205-220.

Longhurst, A., 2007. Ecological Geography of the Sea. Elsevier. doi:10.1016/B978-0-1255521-1.X5000-1

Lutjeharms, J.R.E., de Ruijter, W.P.M., Ridderinkhof, H., van Aken, H., Veth, C., van Leeuwen, P.J., Drijfhout, S.S., Jansen, J.H.F., Brummer, G-J.A., 2000 MARE and ACSEX: new research programmes on the Agulhas Current system. S. Afr. J. Sci. 96, 105-110.

Lutjeharms, J.R.E., Machu, E., 2000. An upwelling cell inshore of the East Madagascar Current. Deep-Sea Res. I Oceanogr. Res. Pap. 47 (12), 2405-2411. doi:10.1016/S09670637(00)00026-1.

Machu, E., Lutjeharms, J., Webb, A., van Aken, H., 2002. First hydrographic evidence of the southeast Madagascar upwelling cell. Geophys. Res. Lett. 29 (21). doi:10.1029/2002GL015381.

Marsac, F., Annasawmy, P., Noyon, M., Demarcq, H., Soria, M., Rabearisoa, N., Bach, P., Cherel, Y., Grelet, J., Romanov, E., 2020a. Seamount effect on circulation and distribution of ocean taxa in the vicinity of La Pérouse, a shallow seamount in the southwestern Indian Ocean. Deep Sea Res. II (this issue).

Marsac, F., Fonteneau, A., Michaud, P., 2014. L'or bleu des Seychelles: histoire de la pêche industrielle au thon dans l'océan Indien. Chap.7: Le coco de mer, une montagne sous la mer. IRD Editions, 269 pp. http://www.editions.ird.fr/produit/978270991759

Marsac, F., Galletti, F., Ternon, J-F., Romanov, E.V., Demarcq, H., Corbari, L., Bouchet, P., Roest, W.R., Jorry, S.J., Olu, K., Loncke, L., Roberts, M.J., Ménard, F., 2020b. Seamounts, plateaus and governance issues in the southwestern Indian Ocean, with emphasis on fisheries management and marine conservation, using the Walters Shoal as a case study for implementing a protection framework. Deep-Sea Res. II (this issue).

Menezes, V.V., Phillips, H.E., Schiller, A., Bindoff, N.L., Domingues, C.M.,Vianna, M.L., 2014. South Indian countercurrent and associated fronts. J. Geophys. Res. Oceans, 119, 6763-6791, doi:10.1002/2014JC010076.

Morato, T., Clark, M.R., 2007. Seamount fishes: ecology and life histories. In: Pitcher, T. J., Morato, T., Hart, P.J.B., Clark, M.R., Haggan, N., Santos, R.S. (Eds.), Seamounts: Ecology, Fisheries and Conservation 12. Blackwell Publishing, Oxford, U.K, pp. 170188.

MRAG, 2005. Review of Impacts of Illegal, Unreported and Unregulated Fishing on Developing Countries. Report to DFID. 176 pp.

Munschy, M., Schlich, R., 1989. The Rodriguez Triple Junction (Indian Ocean): structure and evolution for the past one million years. Mar. Geophys. Res. 11, 1-14.

Mullineaux, L.S.P, Mills, S.W.A. 1997. A test of the larval retention hypothesis in seamountgenerated flows. Deep-Sea Research Part I: Oceanographic Research Papers, 44, 745770.

Norse, E.A., Brooke, S., Cheung, W.W.L., Clark, C.W., Clark, M.R., Ekeland, I., Froese, R., Gjerde, K.M., Haedrich, R.L., Heppell, S.S., Morato, T., Morgan, L.E., Pauly, D., Sumaila, R., Watson, R. 2011. Sustainability of deep-sea fisheries. Mar. Pol. 36, 307320.

Noyon, M., Morris, T., Walker, D., Huggett, J., 2019. Plankton distribution within a young cyclonic eddy off south-western Madagascar. Deep Sea Res. II. Top. Stud. Oceanogr. 166, 141-150. doi:10.1016/j.dsr2.2018.11.001. 
Noyon, M., Rasoloarijao, Z., Huggett, J., Ternon, J-F., Roberts, M., 2020. Comparison of mesozooplankton communities at three shallow seamounts in the South West Indian Ocean. Deep Sea Res. II (this issue).

Palastanga, V., van Leeuwen, P.J., Schouten, M.W., de Ruijter, W.P.M., 2007. Flow structure and variability in the subtropical Indian Ocean: instability of the South Indian Counter Current, J. Geophys. Res., 112, C01001, doi:10.1029/2005JC003395.

Parin, N.V., Nesis, K.N., Sagaidachny, A.Y., Shcherbachev, Y.N., 1993. Fauna of Walters shoal, a seamount in the southwestern Indian Ocean. Trudy Inst. Okeanol. 128, 199-216 [in Russian].

Parin, N.V., Timokhin, I.G., Novikov, N.P., Shcherbachev, Yu.N., 2008. On the composition of talassobathyal ichthyofauna and commercial productivity of Mozambique Seamount (the Indian Ocean). J. Ichthyol, 48(5): 361-366.

Pinet, P., Jaquemet, S., Phillips, R.A., Le Corre, M., 2012. Sex-specific foraging strategies throughout the breeding season in a tropical, sexually monomorphic small petrel. Anim. Behav. 83, 979-989. doi:/10.1012/j.anbehav.2012.01.19

Pitcher, T.J., Bulman, C., 2007. Raiding the larder: a quantitative evaluation framework and trophic signature for seamount food webs. In Pitcher, T.J., Morato, T., Hart, P.J.B., Clark, M.R., Haggan, N., Santos, R.S. (Eds.), Seamounts: Ecology, Fisheries and Conservation 12. Blackwell Publishing, Oxford, U.K, 3-25.

Pitcher, T.J., Clark, M.R., Morato, T., Watson, R., 2010. Seamount fisheries: do they have a future? Oceanogr. 23, 134-144.

Pollard, R., Read, J., 2015. Circulation, stratification and seamounts in the south west Indian Ocean. Deep-Sea Res. II 136, 36-43. doi:/10.1016/j.dsr2.2015.02.018

Potier, M., Marsac, F., Cherel, Y., Lucas, V., Sabatié, R., Maury, O., Ménard, F., 2007. Forage fauna in the diet of three large pelagic fishes (lancetfish, swordfish and yellowfin tuna) in the western equatorial Indian Ocean. Fish. Res. 83, 60-72.

Quartly, G.D., 2006. RRS Discovery Cruise 288, 26 Jan - 21 Feb 2005. Madagascar Experiment (MadEx) (National Oceanography Centre Southampton Cruise Report, 8) Southampton, UK. National Oceanography Centre Southampton. 105 pp.

Ramanantsoa,, J. D., Krug, M., Penven, P., Rouault, M., Gula, J., 2018. Coastal upwelling south of Madagascar: temporal and spatial variability. J. Mar. Syst. 178, 29-37. doi:10.1016/j.jmarsys.2017.10.005

Richer de Forges, B., Koslow, J.A., Poore, G.C.B., 2000. Diversity and endemism of the benthic seamount fauna in the southwest Pacific. Nature, 405, 944-947.

Ridderinkhof, W., Le Bars, D., von der Heydt, A.S., de Ruijter, W.P.M., 2013. Dipoles of the South East Madagascar Current. Geophys. Res. Lett. 40(3), 558-562.

Roberts, C.M., 2002. Deep impact: the rising toll of fishing in the deep sea. Trends Ecol. Evol. 17, 242-245

Roberts, M., 2015. The Western Indian Ocean Upwelling Research Initiative (WIOURI): a Flagship IIOE2 Project. CLIVAR Exchanges No. 68, Vol. 19, No. 3, Nov 2015.

Rocke, E., Noyon, M., Roberts, M., 2020. Picoplankton and nanoplankton composition on and around a seamount, affected by an eddy dipole south of Madagascar. Deep Sea Res. II (this issue).

Rogers, A.D., 1994. The biology of seamounts. Adv. Mar. Biol. 30, 305-50.

Rogers, A.D., 2018. The biology of seamounts: 25 years on. Adv. Mar. Biol. 79, 137-224. doi: 10.1016/bs.amb.2018.06.001

Rogers, A.D., 2019. Threats to seamount ecosystems and their management. In: Charles Sheppard (Ed.), World Seas: an Environmental Evaluation ( $2^{\text {nd }}$ edn), Academic Press, pp. 427-451, ISBN 9780128050521. 
989

990

991

992

993

994

995

996

997

998

999

1000

1001

1002

1003

1004

1005

1006

1007

1008

1009

1010

1011

1012

1013

1014

1015

1016

1017

1018

1019

1020

1021

1022

1023

1024

1025

1026

1027

1028

1029

1030

1031

1032

1033

1034

1035

1036

1037

Rogers, A.D., Alvheim, O., Bemanaja, E. et al., 2017. Pelagic communities of the South West Indian Ocean seamounts: R/V Dr Fridtjof Nansen cruise 2009-420. Deep Sea Res II 136, 5-35.

Romanov, E.V. (ed.), 2003. Summary and review of Soviet and Ukrainian scientific and commercial fishing operations on the deep water ridges of the southern Indian Ocean. FAO Fish. Circ. 991. Rome, FAO, 84 pp.

Rosenbaum, H.C., Razafindrakoto, Y., Vaohavy, J., Pomilla, C., 2001. A note on recent sightings of southern right whales (Eubalaena australis) along the east coast of Madagascar. J Cetacean Res. Man. (Special Issue) 2, 177-180.

Rowden, A.A., Schlacher, T.A., Williams, A., Clark, M.R., Stewart, R., Althaus, F., Bowden, D.A., Consalvey, M., Robinson, W., Dowdney, J., 2010. A test of the seamount oasis hypothesis: seamounts support higher epibenthic megafaunal biomass than adjacent slopes. Mar. Ecol. 31, 95-106.

Samadi, S., Schlacher, T., Richer de Forges, B., 2007. Seamount benthos. In Pitcher, T.J., Morato, T., Hart, P.J.B., Clark, M.R., Haggan, N., Santos, R.S. (Eds.), Seamounts: Ecology, Fisheries and Conservation 12. Blackwell Publishing, Oxford, U.K, 119-140.

Sauter, D., Cannat, M., 2010. The ultraslow spreading Southwest Indian Ridge. In: Rona P.A., Devey C.W., Dyment J., Murton B.J. Diversity of Hydrothermal Systems on Slow Spreading Ocean Ridges. Geophys. Monogr. Ser. 188, 153-173.

Siedler, G., Rouault, M., Biastoch, A., Backeberg, B., Reason, C.J.C., Lutjeharms, J.R.E., 2009. Modes of the southern extension of the East Madagascar Current. J. Geophys. Res. 114(C01005).

Srokosz, M.A., Quartly, G.D., Buck, J.J.H., 2004. A possible plankton wave in the Indian Ocean. Geophys. Res. Lett., 31, L13301, doi:10.1029/2004GL019738.

Tittensor, D.P., Baco, A.R., Brewin, P.E., Clark M.R., Consalvey, M., Hall-Spencer, J.M., Rowden, A.A., Schlacher, T, Stocks, K.I., Rogers A.D., 2009. Predicting global habitat suitability for stony corals on seamounts. J. Biogeogr. 36, 1111-1128

Vianello, P., Ternon, J-F., Demarcq, H., Herbette, S., Roberts, M.J., 2020a. Ocean currents and gradients of surface layer properties in the vicinity of the Madagascar Ridge, South West Indian Ocean. Deep-Sea Res. II (this issue).

Vianello, P., Herbette, S., Ternon, J-F., Demarcq, H., Roberts, M.J., 2020b. Observation of a mesoscale eddy dipole on the northern Madagascar Ridge: consequences for the circulation and hydrography in the vicinity of a seamount. Deep-Sea Res. II (this issue).

Voldsund, A., Aguiar-González, B., Gammelsrød, T, Krakstad, J-O., Ullgren, J., 2017. Observations of the East Madagascar Current system: dynamics and volume transports. J. Mar. Res. 75, 531-555.

Vousden, D., Scott, L.E.P., Sauer, W., Bornman, T.G., Ngoile, M., Stapley, J., Lutjeharms, J.R.E., 2008. Establishing a basis for ecosystem management in the western Indian Ocean. S. Afr. J. Sci. 104, 417-420.

Wessel, P. 2007. Seamount characteristics. In Pitcher, T.J., Morato, T., Hart, P.J.B., Clark, M.R., Haggan, N., Santos, R.S. (Eds.), Seamounts: Ecology, Fisheries and Conservation 12. Blackwell Publishing, Oxford, UK, 3-25.

White, M., Bashmachnikov, I., Arístegui, J., Martins, A., 2007. Physical processes and seamount productivity, in: Pitcher, T.J., Morato, T., Hart, P.J.B., Clark, M.R., Haggan, N., Santos, R.S. (Eds.), Seamounts: Ecology, Fisheries and Conservation. Blackwell Publishing, Oxford, UK, 65-84.

Yesson, C., Clark, M.R., Taylor, M.L., Rogers, A.D., 2011. The global distribution of seamounts based on 30 arc seconds bathymetry data. Deep-Sea Res. I: Oceanogr. Res. Pap. 58(4), 442-453. doi: 10.1016/j.dsr.2011.02.004 
Zeitzschel, B. 1973. The Biology of the Indian Ocean. Springer, New York. Ecol. Stud. 3. 549 pp.

Zhao, Z-X., Alford, M.H., Girton, J.B., Rainville, L., Simmons, H.L., 2016. Global observations of open-ocean Mode- $1 \mathrm{M}_{2}$ internal tides. J. Phys. Oceanogr. 46, 16571684, doi:10.1175/JPO-D-15-0105.1

\section{Figure Legends}

Figure 1: (a) Global distribution of seamounts. Based on GEBCO_2014 bathymetric data (adapted after Rogers, 2019). The South West Indian Ridge is highlighted, as examples of well-studied chains. The three seamounts examined by the MAD-Ridge project are depicted. (b) Global distribution of marine mining and exploration contracts (after Rogers, 2018).

Figure 2: Map of seamounts explored by the Russian/Ukrainian fishing fleet in the Southwestern Indian Ocean between 1972 and 2000 (after Romanov, 2003).

Figure 3: Bathymetry (see depth scale) of the Western Indian Ocean highlighting the Madagascar Ridge (Plateau), the unnamed MAD-Ridge seamount $(240 \mathrm{~m})$ and the Walters Shoal seamount $(18 \mathrm{~m})$ on the northern and southern parts of the ridge respectively, and the La Pérouse seamount $(60 \mathrm{~m})$ northwest of Réunion Island (white text). Grey lines delineate EEZs. Red dots indicate seamounts sampled during the IUCN Seamounts Project.

Figure 4: Seabird hotspots in the western Indian Ocean, based on satellite tracking data. (a) Number of tracking detections calculated per cell of $1^{\circ} \times 1^{\circ}$ (after Le Corre et al., 2012). (b) Density distributions of Barau's petrels during the breeding season, short trips vs. long trips of 10 birds (after Pinet et al., 2012).

Figure 5: Longline catches (by $5^{\circ}$ square) of yellowfin (YFT) and bigeye (BET) tuna, albacore (ALB) and swordfish (SWO) in tonnes between 1995 and 2017, combining all longline fleet data operating in the Indian Ocean. The $2000 \mathrm{~m}$ isobath is represented by a black line (data sources: IOTC C/E database, 2018, and ETOPO1 database).

Figure 6: (a) Modelled speed and velocity at $100 \mathrm{~m}$, as a 5-day average, around 21 May 1997 highlighting major ocean current features of the SWIO (after Biastoch et al., 2009). (b) TKE (total kinetic energy, $\mathrm{cm}^{2} \mathrm{~s}^{-2}$ ) indicating highly energetic regions (1993-2017 average, from altimetry).

Figure 7: Sampling patterns used for the various cruises and legs. (a) Overview map; (b) La Pérouse September 2016; (c) MAD-Ridge Leg 1 November 2016; (d) Zoom-in over the summit; (e) and (f) Walters Shoal April/May 2017. 

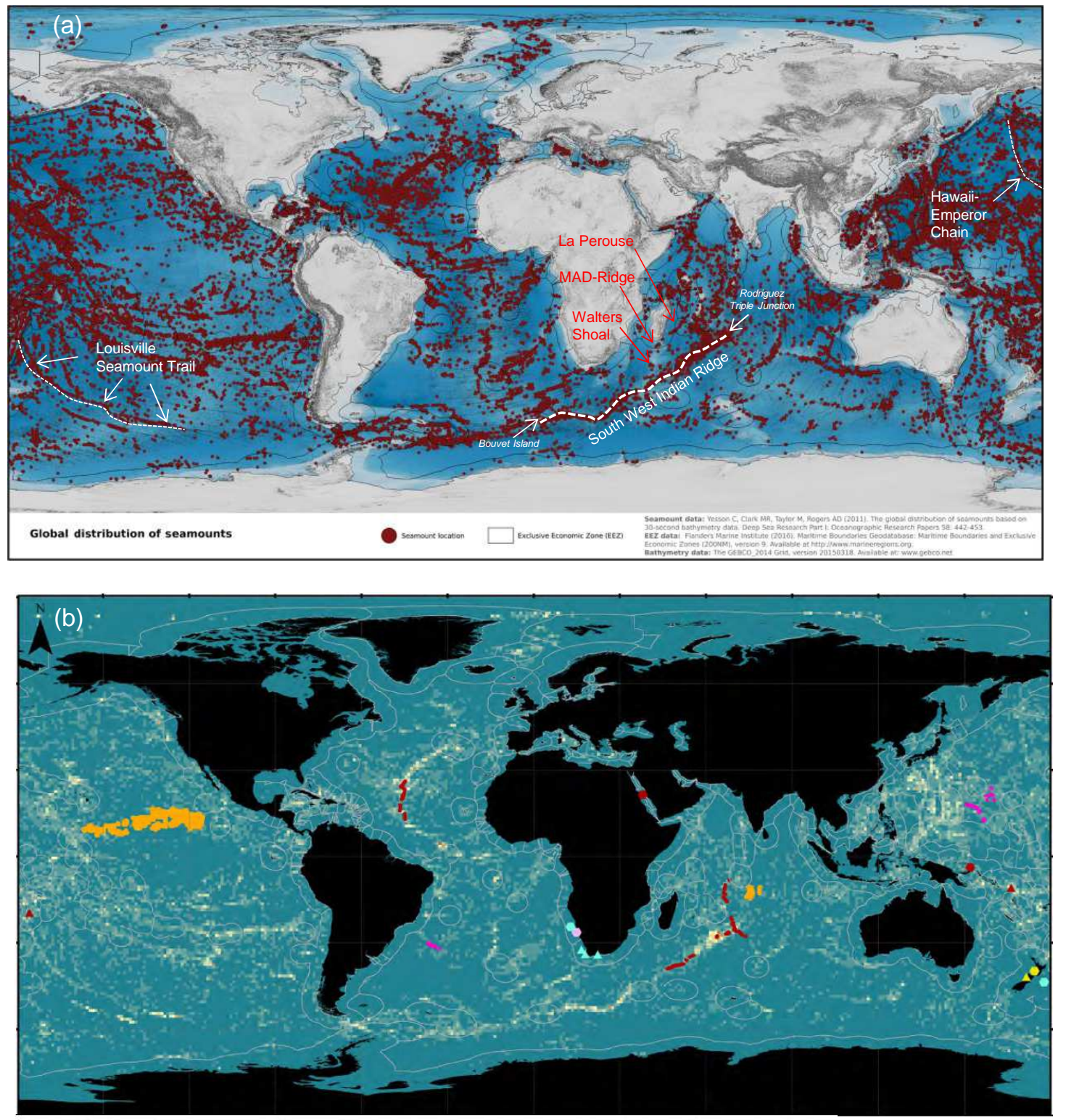

Global distribution of marine mining and exploration contracts

$\begin{array}{lll}\text { Contracts within the area } & \text { Contracts within EEZs } & \text { Phosphorites, mining contract } \\ \text { Cobalt-rich ferromanganese crusts } & \text { Diamonds, mining contract } & \text { Phosphorites, prospecting contract } \\ \text { Manganese nodules } & \text { Iron ore sands, mining contract } & \text { - SMS, mining contract }\end{array}$

Figure 1: (a) Global distribution of seamounts. Based on GEBCO_2014 bathymetric data (adapted after Rogers, 2019). The South West Indian Ridge is highlighted, as examples of well-studies chains. The three seamounts examined by the MAD-Ridge project are depicted. (b) Global distribution of marine mining and exploration contracts. (after Rogers, 2018). 


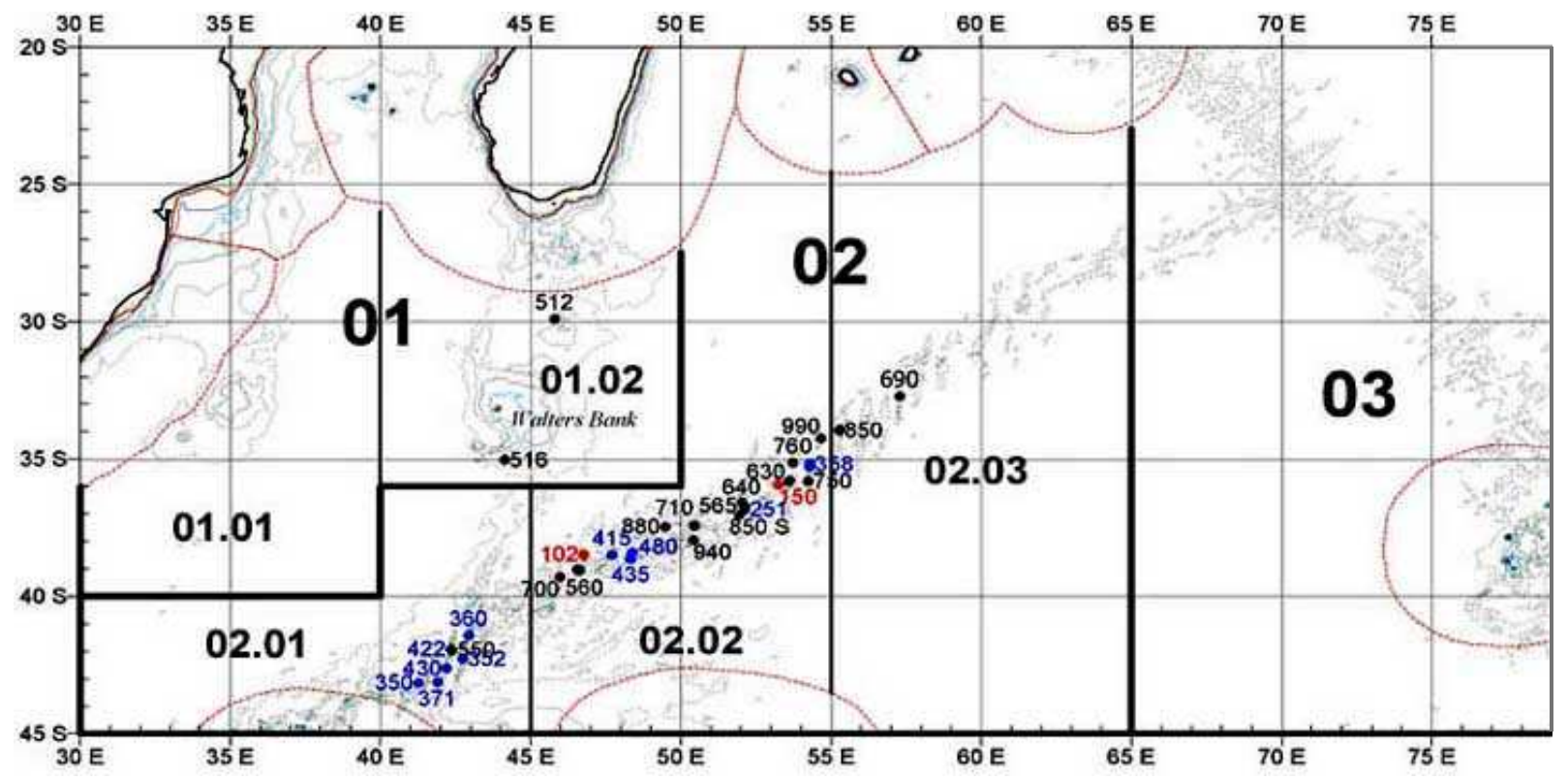

Figure 2: Map of seamounts explored by the Russian/Ukrainian fishing fleet in the South-western Indian Ocean between 1972 and 2000 (after Romanov, 2003). 


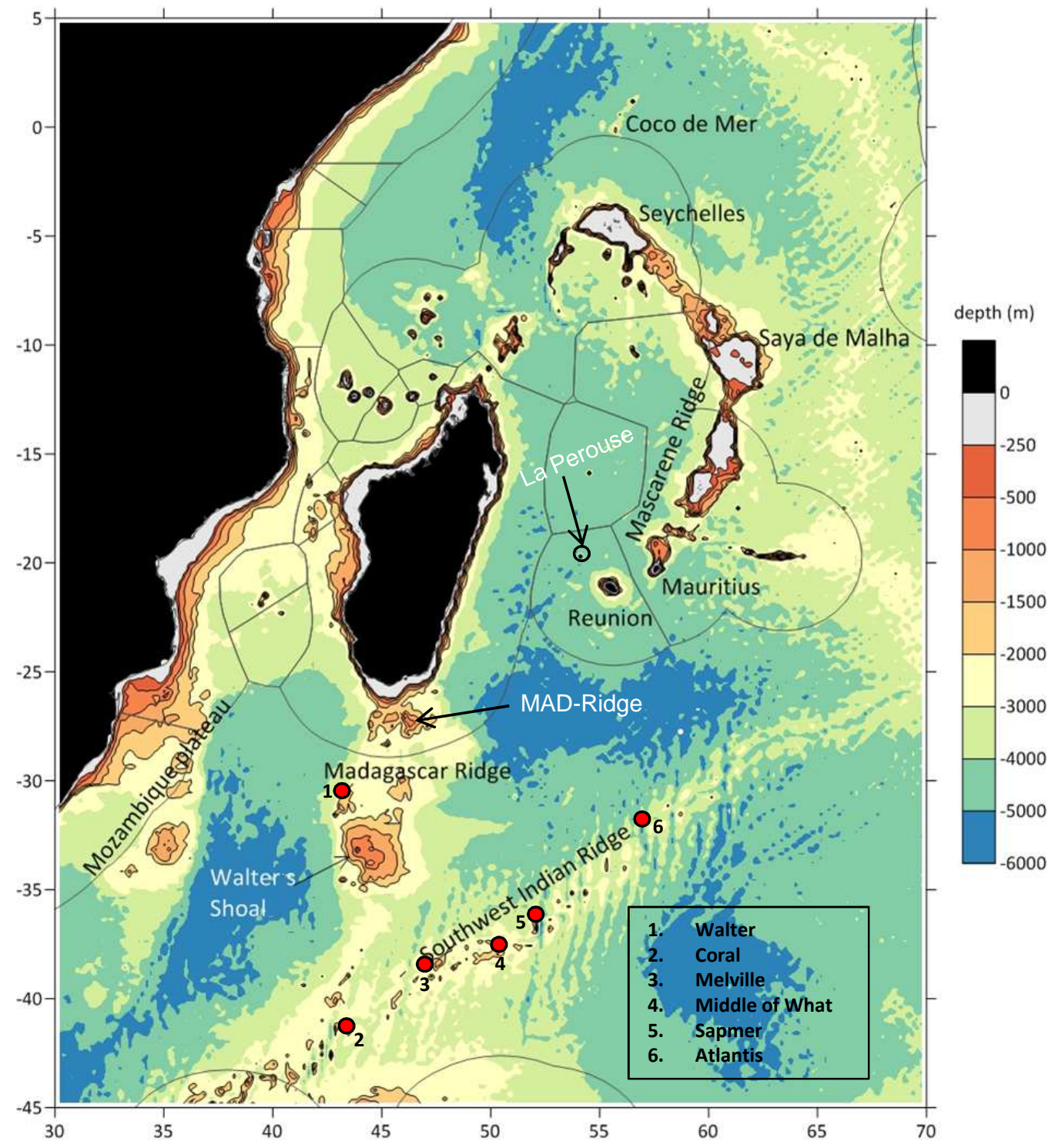

Figure 3: Bathymetry (see depth scale) of the Western Indian Ocean highlighting the Madagascar Ridge (Plateau), the unnamed 'MAD-Ridge' (240 m) and Walters Shoal (18 m) seamounts on the northern and southern parts of the ridge respectively, and the $\mathrm{La}$ Pérouse seamount $(60 \mathrm{~m})$ northwest of Réunion Island (white text). Grey lines delineate EEZs. Red dots indicate seamounts sampled during the IUCN Seamounts Project. 

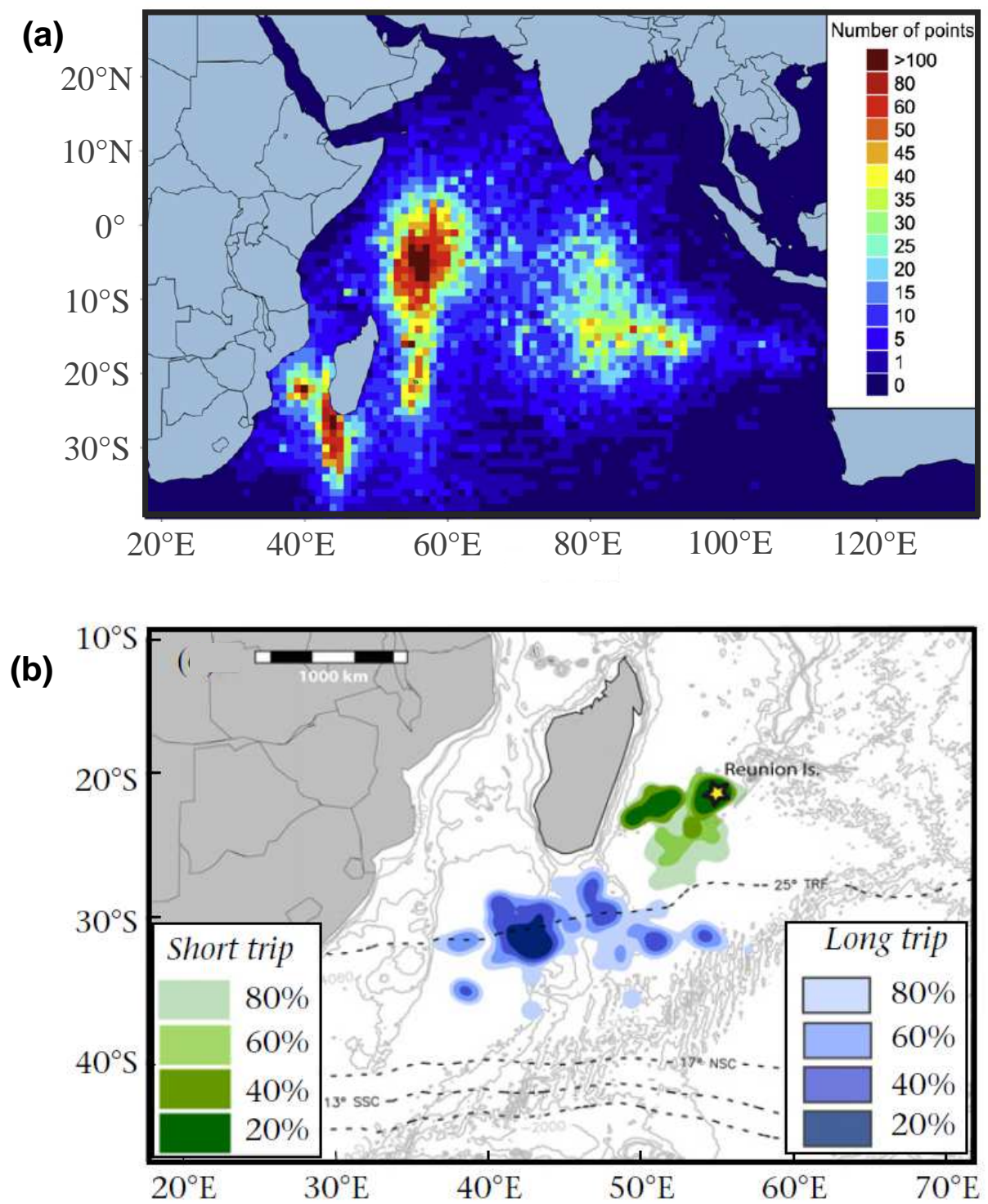

Figure 4: Seabird hotspots in the western Indian Ocean, based on satellite tracking data. (a) Number of tracking detections calculated per cell of $1^{\circ} \times 1^{\circ}$ (after Le Corre et al. 2012). (b) Density distributions of Barau's petrels during the breeding season, short trips versus long trips of 10 birds (after Pinet et al. 2012). 


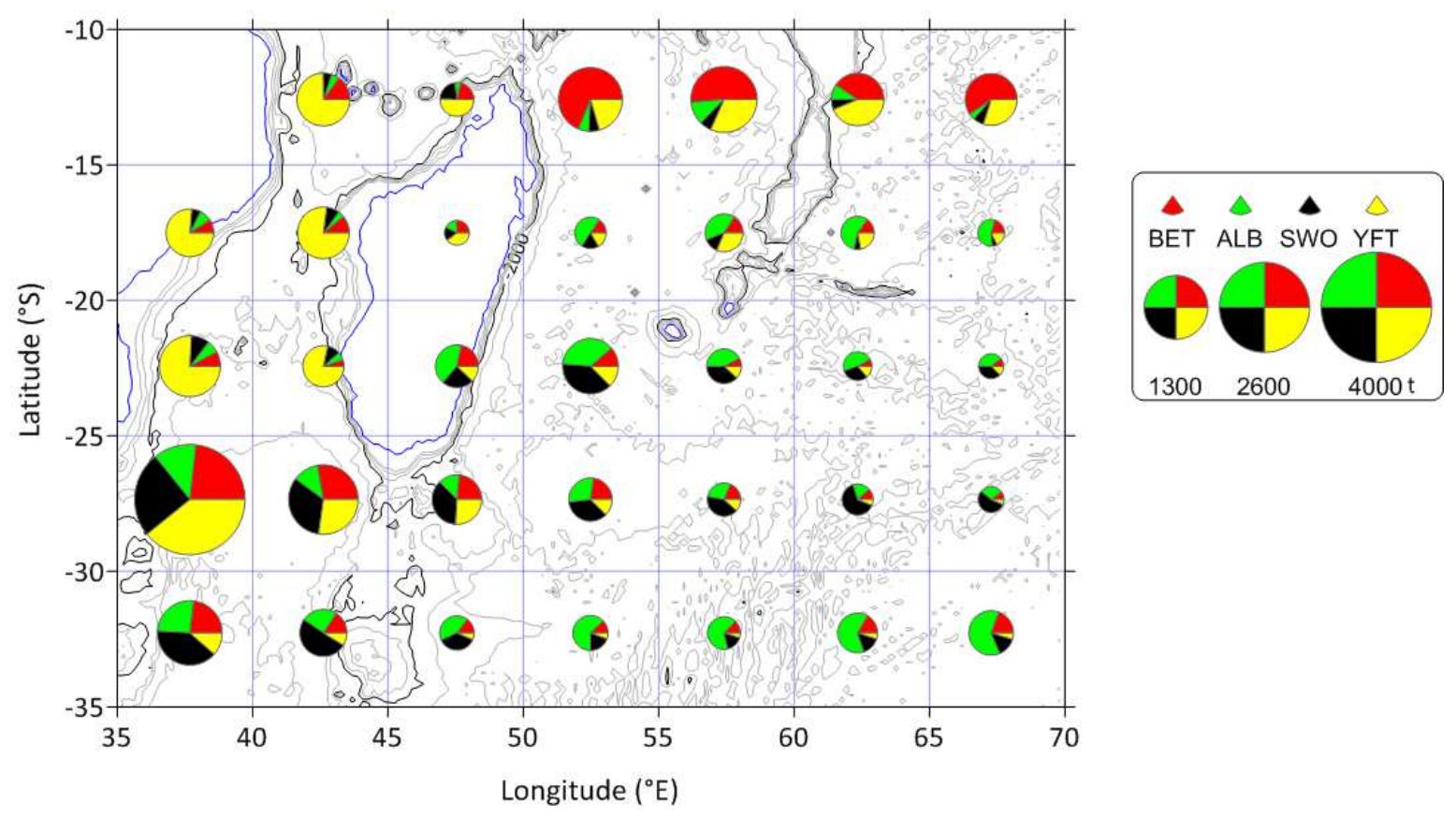

Figure 5: Longline catches (by $5^{\circ}$ squares) of yellowfin (YFT), bigeye (BET), albacore (ALB) tunas and swordfish (SWO) in tons between 1995 and 2017, combining all longline fleet data operating in the Indian Ocean. The $2000 \mathrm{~m}$ isobath is represented by a black line (Data sources: IOTC C/E database, (2018) and ETOPO1 database). 

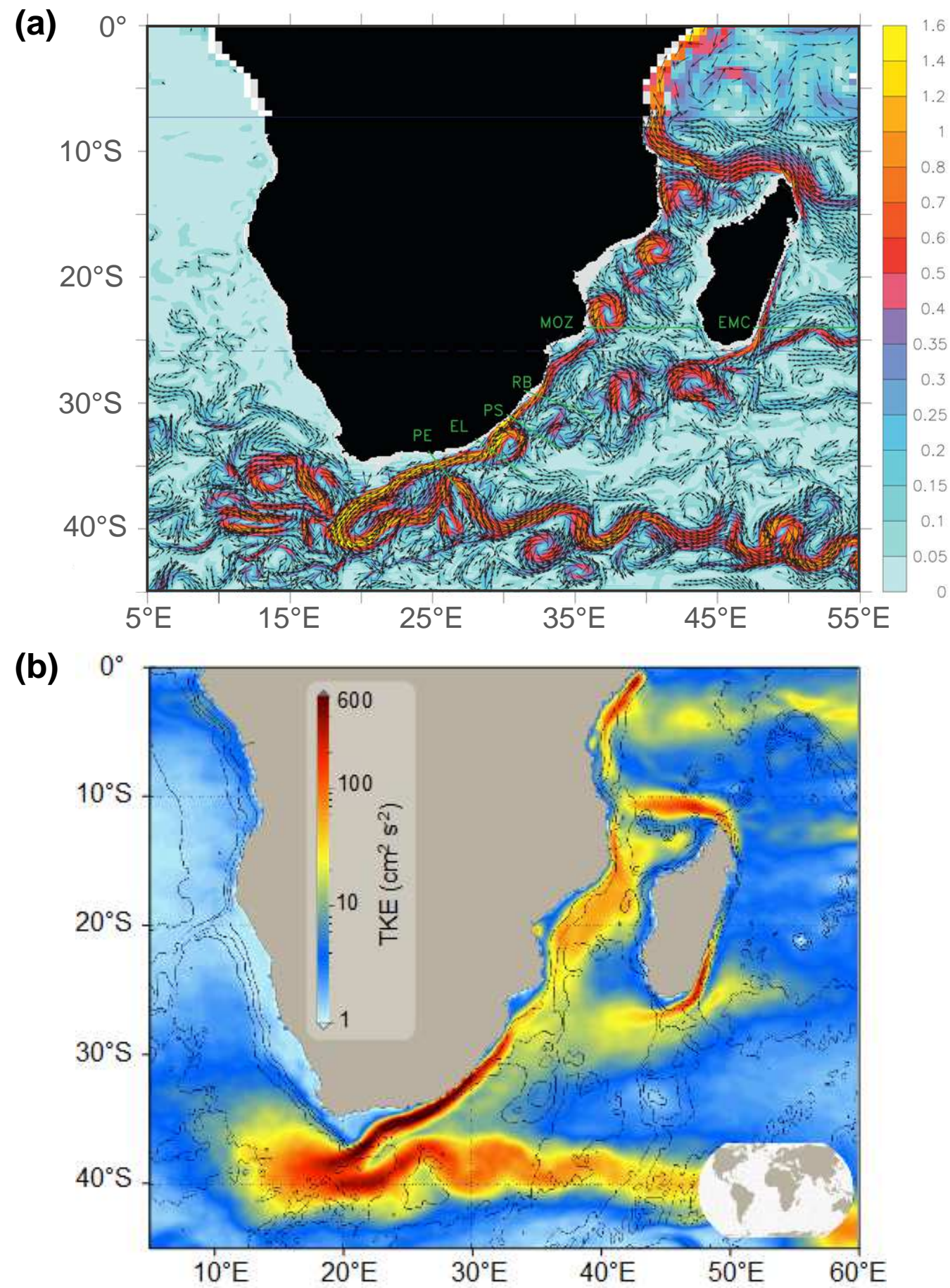

Figure 6: (a) Modelled speed and velocity at $100 \mathrm{~m}$, as a 5-day average, around 21 May 1997 highlighting major ocean current features of the SWIO (after Biastoch et al., 2009). (b) TKE (total kinetic energy, in $\mathrm{cm}^{2} \mathrm{~s}^{-2}$ ) indicating highly energetic regions (1993-2017 average, from altimetry). 
(a) Overview

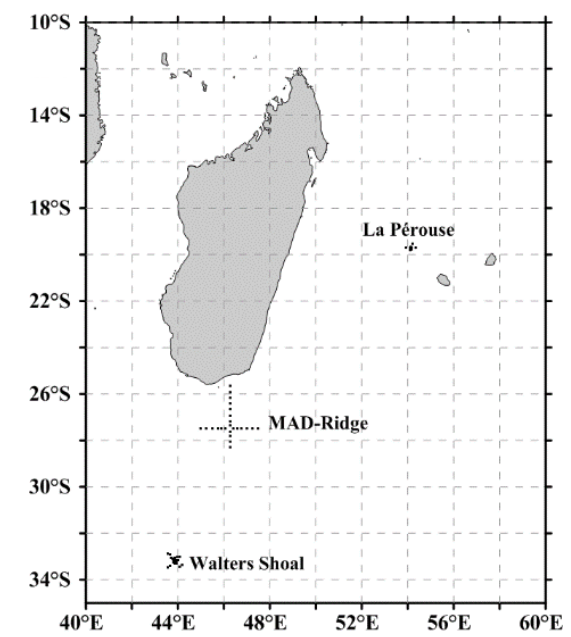

(b) La Pérouse

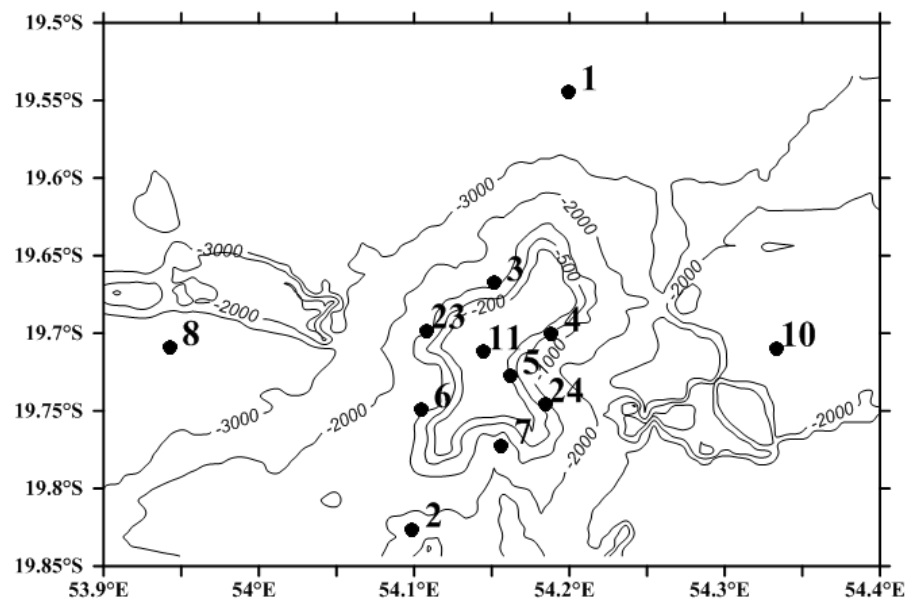

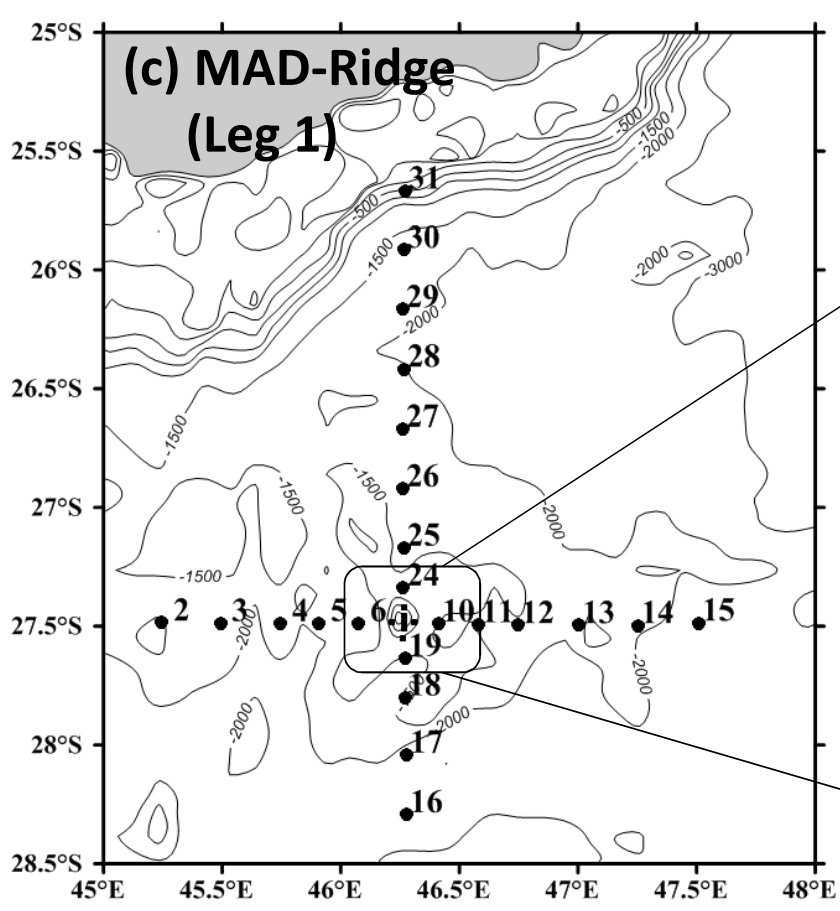

(d) MAD-Ridge pinnacle
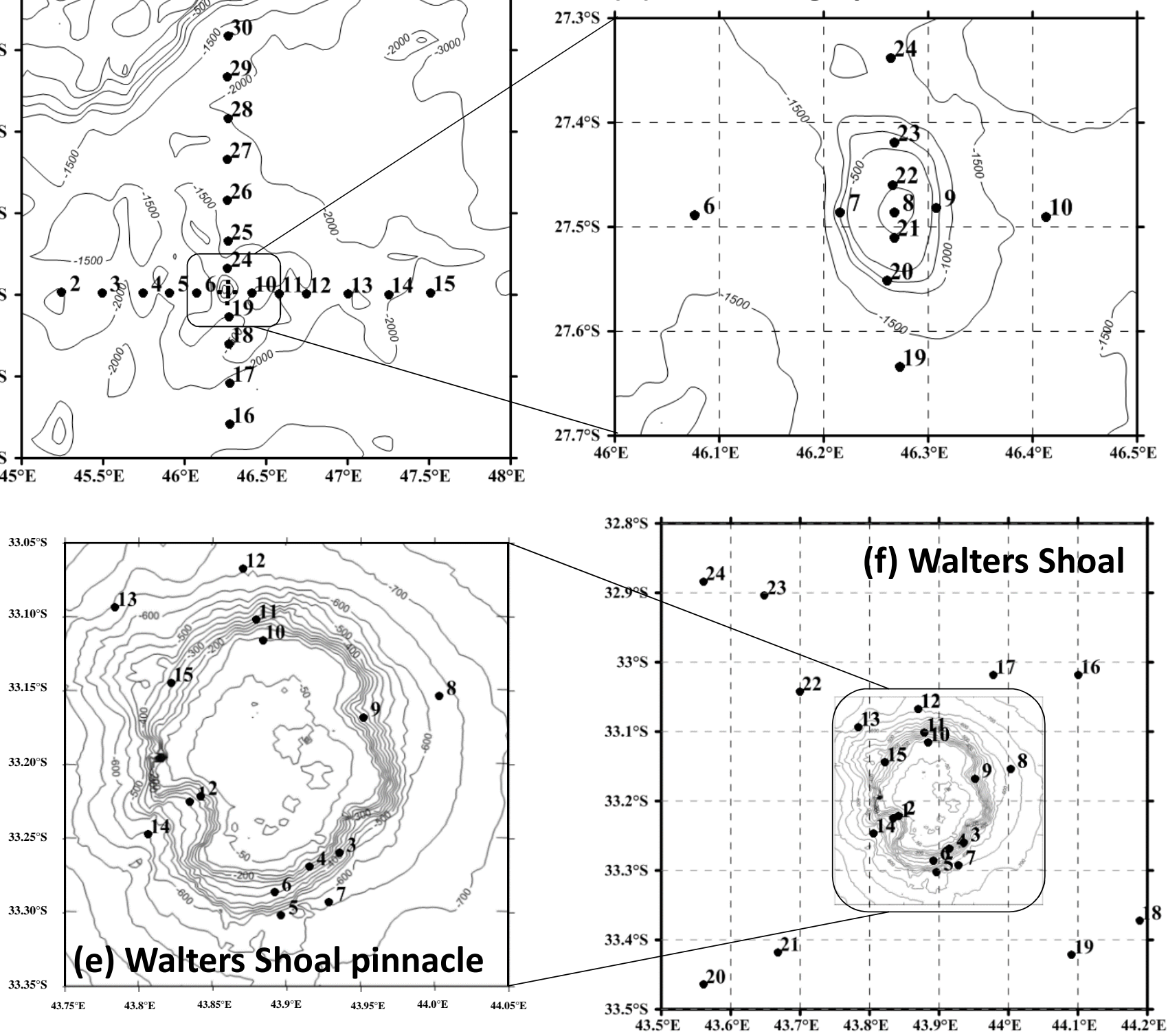

Figure 7: Sampling patterns used for the various cruises and legs. (a) overview map (b) La Pérouse September 2016 (c) MAD-Ridge Leg 1 November 2016 (d) Zoom-in over the summit (e) and (f) Walters Shoal April-May 2017. 


\section{Author's Declaration of Interest}

Regarding the submission of the research manuscript untitled:

\section{The MADRidge Project: Bio-Physical coupling around three shallow seamounts in the South West Indian Ocean}

We wish to confirm that there are no known conflicts of interest associated with this publication and there has been no significant financial support for this work that could have influenced its outcome.

We confirm that the manuscript has been read and approved by all named authors and that there are no other persons who satisfied the criteria for authorship but are not listed. We further confirm that the order of authors listed in the manuscript has been approved by all of us.

We confirm that we have given due consideration to the protection of intellectual property associated with this work and that there are no impediments to publication, including the timing of publication, with respect to intellectual property. In so doing we confirm that we have followed the regulations of our institutions concerning intellectual property.

We confirm that the work described has not been published previously, that it is not under consideration for publication elsewhere, that its publication is approved by all authors and that, if accepted, it will not be published elsewhere in the same form, in English or in any other language, including electronically without the written consent of the copyright-holder.

We further confirm that any aspect of the work covered in this manuscript that has involved experimental animals has been conducted with the ethical approval of all relevant bodies.

We understand that the Corresponding Author is the sole contact for the Editorial process (including Editorial Manager and direct communications with the office). She is responsible for communicating with the other authors about progress, submissions of revisions and final approval of proofs. We confirm that we have provided a current, correct email address which is accessible by the Corresponding Author and which has been configured to accept email from jean-francois.ternon@ird.fr

Signed by all authors as follows: 


\section{LIST OF AUTHORS}

Michael J. Roberts

Date 03/06/2020

Signature

Jean-François Ternon (corresponding author)

Date 03/06/2020

Signature

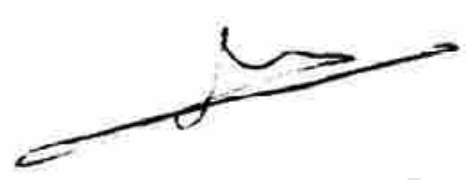

Francis Marsac

Date $03 / 06 / 2020$

Signature

Margaux Noyon

Date $03 / 06 / 2020$

Signature

Andrew I.L Payne

Date $03 / 06 / 2020$

Signature 